\title{
Iterative Cellular Screening System for Nanoparticle Safety Testing
}

\author{
Franziska Sambale, ${ }^{1}$ Frank Stahl, ${ }^{1}$ Ferdinand Rüdinger, ${ }^{1}$ Dror Seliktar, ${ }^{2}$ Cornelia Kasper, \\ Detlef Bahnemann, ${ }^{1,4}$ and Thomas Scheper ${ }^{1}$ \\ ${ }^{1}$ Institute for Technical Chemistry, Gottfried Wilhelm Leibniz University Hanover, Callinstraße 5, 30167 Hanover, Germany \\ ${ }^{2}$ Faculty of Biomedical Engineering, Technion Israel Institute of Technology, 32000 Haifa, Israel \\ ${ }^{3}$ Institute of Applied Microbiology, University of Natural Resources and Life Science (Boku), Muthgasse 18, 1190 Vienna, Austria \\ ${ }^{4}$ Laboratory "Photoactive Nanocomposite Materials", Saint Petersburg State University, Ulyanovskaya Street 1, Peterhof, \\ Saint Petersburg 198504, Russia
}

Correspondence should be addressed to Frank Stahl; stahl@iftc.uni-hannover.de

Received 14 April 2015; Revised 1 July 2015; Accepted 8 July 2015

Academic Editor: Jin-Ho Choy

Copyright (C) 2015 Franziska Sambale et al. This is an open access article distributed under the Creative Commons Attribution License, which permits unrestricted use, distribution, and reproduction in any medium, provided the original work is properly cited.

\begin{abstract}
Nanoparticles have the potential to exhibit risks to human beings and to the environment; due to the wide applications of nanoproducts, extensive risk management must not be neglected. Therefore, we have constructed a cell-based, iterative screening system to examine a variety of nanoproducts concerning their toxicity during development. The sensitivity and application of various cell-based methods were discussed and proven by applying the screening to two different nanoparticles: zinc oxide and titanium dioxide nanoparticles. They were used as benchmarks to set up our methods and to examine their effects on mammalian cell lines. Different biological processes such as cell viability, gene expression of interleukin-8 and heat shock protein 70 , as well as morphology changes were investigated. Within our screening system, both nanoparticle suspensions and coatings can be tested. Electric cell impedance measurements revealed to be a good method for online monitoring of cellular behavior. The implementation of three-dimensional cell culture is essential to better mimic in vivo conditions. In conclusion, our screening system is highly efficient, cost minimizing, and reduces the need for animal studies.
\end{abstract}

\section{Introduction}

Nanoparticles have been used in many applications over the last decades such as cosmetics, medicine, and paints. In 2012 more than 100 products containing nanoparticles were available [1]. However, the constantly increasing amount of industrial as well as consumer nanoproducts requires reliable and extensive risk management, as interactions with human beings and the environment are becoming more frequent. Various public exposure paths are possible [2], but up to now no standardized guideline for nanoparticle and nanomaterials testing exists $[1,3]$. Currently for nanoparticle testing in vitro, only the commonly used assays validated for drug testing are available. However, nanoparticles differ significantly from normal chemicals [2] and can interfere with the assays [1-4].
In particular, oxidized nanoparticles are able to reduce assay dyes, causing an underestimation of the cytotoxicity by overestimating cell viability [5]. Furthermore, a key challenge of in vitro nanoparticle safety testing is determining the stability of nanoparticles in biological media. For a plurality of nanoparticles, stable nanoparticle suspensions exhibit an acidic $\mathrm{pH}$ value and/or contain different stabilizing agents. Thus, adding nanoparticles for in vitro cytotoxicity assays directly to the physiological aqueous culture media often results in nanoparticle aggregation and agglomeration $[2,6$, 7].

While these limitations in nanoparticle cytotoxicity measurements are known, as long as alternative assays have not been developed, careful examinations of the results are needed. Furthermore, when choosing a method for nanoparticle testing it must be excluded that false-positive 
results can be misinterpreted. Nevertheless, for nanoparticle cytotoxicity studies in vitro, cell-exposure studies can yield the first evidence of their potential risk. These tests offer the advantages to be simple and to clarify the basic interaction [1]. Additionally, these methods are rapid, cheaper, and more reproducible than in vivo systems [1]. Thus, in vitro studies are often used before animal studies are applied. However, there are concerns whether the results of these studies can really predict in vivo cell behavior. A comparative study of the effects of $\mathrm{TiO}_{2}$ nanoparticles demonstrated a good correlation between acute toxicity measurements of in vitro and in vivo tests based on the steepest slopes of dose response curves [8]. Moreover, Kim et al. could identify higher cytotoxicity of nanosized $\mathrm{SiO}_{2}$ as compared with microsized particles in vitro as well as in vivo [9].

To improve the prediction of in vivo effects a set of in vitro assays investigating different mechanism is needed [9]. As in vitro assays cannot mimic real tissue conditions also more complex in vitro models like three-dimensional (3D) cell culture models could bridge the gap between classical two-dimensional (2D) in vitro models and in vivo studies.

The development of consumer nanomaterials implies long optimization procedures resulting in the formation of plenty of precursors and intermediates. All these materials may pose risks to human beings and the environment. All these materials must be tested for toxicity, especially with regards to occupational safety provision and consumer protection. However, the number of in vitro cytotoxicity assays currently available is huge; consequently, all of these assays cannot be applied for all precursors, intermediates, and products. Moreover, animal studies are ethically controversial and therefore limited. Thus, a broad and complex study can often not be performed because the bottlenecks are in vitro cell-based toxicity tests and in vivo animal studies which are very time consuming and costly.

Therefore, the aim of our study was the development of an in vitro hierarchical nanoparticle screening system to examine any kind of nanoparticles concerning their toxicity. First, the structure of the screening system is presented in general. Next is a separate section of the prescreening, fine-screening, and complex-screening where the sensitivity and difficulties of the cytotoxicity assays are discussed. The application of the methods in each screening level was proven exemplary with two different kinds of nanoparticles. This screening system includes different cytotoxic assays and complex cell culture systems such as a three-dimensional cell culture or dynamic cultivation to increase the relevance of in vitro assays. As nanoparticle suspension testing has limitations regarding the cell culture, we studied whether similar results can be obtained with nanoparticle suspensions and with coating experiments, respectively. According to the possible nanoparticle incorporation into the human organism, we used human lung carcinoma A549 cells (respiratory tract) and murine fibroblasts NIH-3T3 cells (skin). As a benchmark-system for the development of the screening system we investigated the effects of zinc oxide nanoparticles ( $\mathrm{ZnO}-\mathrm{NP})$ and titanium dioxide nanoparticles $\left(\mathrm{TiO}_{2}-\mathrm{NP}\right)$ on mammalian cell lines. These two nanoparticle types have been used in different applications and their influence on $2 \mathrm{D}$ monolayer cultures has been analyzed previously. For $\mathrm{ZnO}-$ NP cytotoxic effects have been published [3, 10-12] while the cytotoxicity of $\mathrm{TiO}_{2}-\mathrm{NP}$ is still a point of discussion. Some studies have reported nontoxic effects for $\mathrm{TiO}_{2}-\mathrm{NP}[13,14]$ whereas other studies suggested cytotoxic effects of $\mathrm{TiO}_{2}-\mathrm{NP}$ [14-16]. In the present study both types of nanoparticles were screened with the developed screening system.

\section{Materials and Methods}

2.1. Nanoparticles. In this study $\mathrm{ZnO}-\mathrm{NP}$ (with $0.1 \% \mathrm{Ru}$ ) were used, which were synthesized and characterized by Bloh et al. $(2012,2014)[17,18]$. The $\mathrm{ZnO}-\mathrm{NP}$ have a BrunauerEmmett-Teller (BET) surface of $6.54 \mathrm{~m}^{2} / \mathrm{g}$ and a particle size of $50 \pm 10 \mathrm{~nm}$ (X-ray) [17]. ZnO-NP exhibited an average hydrodynamic diameter (dynamic light scattering) of $41 \pm 5 \mathrm{~nm}$ in water, $190 \pm 3 \mathrm{~nm}$ in Dulbecco's Modified Eagle Medium (DMEM), and $106 \pm 11 \mathrm{~nm}$ in the standard culture medium (mean \pm standard derivation) [19]. The $\mathrm{TiO}_{2}-$ NP (Hombikat XXS 700) were obtained from Sachtleben, Duisburg, Germany, exhibiting a primary particle size of $7 \mathrm{~nm}$ (REM) in the anatase form according to the data sheet. The hydrodynamic diameter of $\mathrm{TiO}_{2}-\mathrm{NP}$ has been reported previously by Sambale et al. [19]. In water $\mathrm{TiO}_{2}-\mathrm{NP}$ have a diameter of $79 \pm 25 \mathrm{~nm}$, in DMEM $142 \pm 29 \mathrm{~nm}$, and in the culture medium $118 \pm 28 \mathrm{~nm}$ [19].

2.2. Cell Culture. A549 human lung carcinoma cells (DSMZ number: ACC 107) and NIH-3T3 mouse fibroblasts cells (DMSZ number: ACC 59) were purchased from the German Collection of Microorganisms and Cell Cultures (DSMZ). Both cell lines used here were cultivated in Dulbecco's Modified Eagle's Medium (DMEM) (D7777 Sigma-Aldrich, Steinheim, Germany) supplemented with $10 \%$ fetal calf serum (FCS) and $100 \mu \mathrm{g} / \mathrm{mL}$ antibiotics (penicillin/streptomycin) in a humidified environment at $37^{\circ} \mathrm{C} / 5 \% \mathrm{CO}_{2}$. Every 3 or 4 days cells were subcultivated when the cultures reached $70-80 \%$ confluence. The passage number of all used cells was less than 20.

2.3. 3D Cell Culture. For 3D cell cultures, two different 3D cell culture models were performed. 20,000 cells were seeded on each side of a round scaffold of $1 \mathrm{~mm}$ thickness and $7 \mathrm{~mm}$ diameter via pipetting (Matriderm, Medskin Solution Dr. Suwelack AG, Germany). The scaffolds were placed in a 24-well plate and were incubated at $37^{\circ} \mathrm{C} / 5 \% \mathrm{CO}_{2}$ for $72 \mathrm{~h}$ to allow the cells to adhere and to build a 3D structure. Afterwards, the cells were treated in triplicate with different concentrations of $\mathrm{ZnO}-\mathrm{NP}$ or $\mathrm{TiO}_{2}-\mathrm{NP}$ in the cell culture medium for $24 \mathrm{~h}$. As a second model, cell encapsulation in a semisynthetic PEG-fibrinogen-based hydrogel (Faculty of Biomedical Engineering, Technion, Haifa, Israel) was investigated. Here, $1 \mathrm{~mL}$ hydrogel (fibrinogen concentration of $8 \mathrm{mg} / \mathrm{mL}$ ) contains $1 \times 10^{6}$ cells and $10 \mu \mathrm{L}$ photoinitiator $(10 \%(\mathrm{w} / \mathrm{v})$ in $70 \%$ ethanol). For generating defined hydrogel constructs, $50 \mu \mathrm{L}$ of the hydrogel-cell-mixture was added to a $6 \mathrm{~mm}$ silicon gasket (Grace Bio-Labs silicone gasket for ProPlate microarray system, Sigma-Aldrich, USA). Covalent 
cross-linking of the hydrogel was performed with UV light (6 W, $365 \mathrm{~nm}$, VL-6L, Vilber Lourmat, France) for 2 min. Then, each hydrogel construct was placed in a 24-well plate containing $500 \mu \mathrm{L}$ cell culture medium. Additionally, hydrogel constructs without cells were used as controls. To allow the cells to adhere in the hydrogel, to proliferate, and to be connected to 3D network the cells were incubated for $48 \mathrm{~h}$ before nanoparticle exposure for $24 \mathrm{~h}$ was performed.

2.4. Nanoparticle Testing. According to their doubling time a defined number of cells were seeded for each cell line. The A549 cells exhibit a doubling time of 40 hours, whereas NIH-3T3 cells exhibit a doubling time of 20 hours. For 2D cell culture experiments 8,000 A549 cells/well and 6,000 NIH-3T3 cells/well were seeded in 96-well plates (Sarstedt AG) and different exposure methods of $\mathrm{ZnO}-\mathrm{NP}$ and $\mathrm{TiO}_{2}$ $\mathrm{NP}$ were investigated. For nanoparticle testing in suspension an aqueous nanoparticle suspension was diluted with cell culture media. The cells were cultured for $24 \mathrm{~h}$ in $100 \mu \mathrm{L}$ standard culture medium before nanoparticle treatment and were exposed to different concentrations of nanoparticles for $24 \mathrm{~h}$ (triplicate). For coating experiments the cells were seeded directly on nanoparticle coatings (triplicate) and cell viability was determined after $48 \mathrm{~h}$. In order to analyze whether nanoparticles have entered the solution from the nanoparticle coatings, extracts were prepared according to the ISO standard 10993-12:2012 (Biological Evaluation of Medical Devices-Part 12: Sample Preparation and Reference Materials) [20]. Therefore, $3 \mathrm{~cm}^{2} / \mathrm{mL}$ cell culture medium was added to the nanoparticles coatings (different concentrations in triplicate) and were placed in an incubator at $37^{\circ} \mathrm{C}$ and $5 \%$ $\mathrm{CO}_{2}$ for $24 \mathrm{~h}$. Then standard culture medium was replaced to the extract medium, and cells were cultured for further $24 \mathrm{~h}$ in the incubator.

2.5. Cell Morphology. The effect of $\mathrm{ZnO}-\mathrm{NP}$ and $\mathrm{TiO}_{2}-\mathrm{NP}$ suspensions on cell morphology in $2 \mathrm{D}$ and in $3 \mathrm{D}$ cell cultures (hydrogel) was examined by phase contrast microcopy (Olympus IX 50, Olympus Corporation, Tokio, Japan) after the cells were exposed to nanoparticles for $24 \mathrm{~h}$.

2.6. Cell Viability. After nanoparticle exposure the cell viability was determined using either the CTB analysis (CellTiterBlue Cell Viability Assay, Promega, Madison, USA) or the MTT assay (Sigma-Aldrich, Munich, Germany). The MTT assay is based on the reduction of the yellow tetrazolium dye MTT to the insoluble blue formazan by metabolic active cells [21]. To perform the MTT assay the cell culture medium was removed from each well and $100 \mu \mathrm{L}(2 \mathrm{D}$ cell culture) $/ 300 \mu \mathrm{L}$ (3D scaffolds) of $10 \%$ MTT solution $(90 \mu \mathrm{L}$ DMEM) and $10 \mu \mathrm{L}$ MTT stock solution $(5 \mathrm{mg} / \mathrm{mL}$ phosphate buffered saline) were added to each well and incubated for $4 \mathrm{~h}$ at $37^{\circ} \mathrm{C} / 5 \% \mathrm{CO}_{2}$. Afterwards $100 \mu \mathrm{L}(2 \mathrm{D}$ cell culture) $/ 200 \mu \mathrm{L}$ (3D scaffolds) sodium dodecyl sulfate (SDS Solution) (1 g SDS in $10 \mathrm{~mL} 0.01 \mathrm{M} \mathrm{HCl}$ ) was added to each well and samples were incubated for further $18 \mathrm{~h}$. To ensure that the formazan was released completely from the scaffold, the samples were shaken at a speed of $700 \mathrm{rpm}$. The absorption signal at $570 \mathrm{~nm} / 630 \mathrm{~nm}$ was determined using a microplate reader (Bio-Rad, Munich, Germany) to quantify the results. Scaffolds without cells were used as background controls.

Comparable to the MTT assay, the CTB assay is based on the reduction of the blue dye resazurin to the purple dye resorufin by metabolically active cells monitored via fluorescence. For the 3D hydrogel cell cultures $100 \mu \mathrm{L}$ CTB stock solution was added to achieve a final concentration of $10 \%$ CTB solution and the dye was incubated for $18 \mathrm{~h}$ at $37^{\circ} \mathrm{C} / 5 \% \mathrm{CO}_{2}$. Samples with hydrogel and different nanoparticle concentrations but without cells were used as background control. The fluorescence signals at an extinction wavelength of $544 \mathrm{~nm}$ and an emission wavelength of $590 \mathrm{~nm}$ were determined using a microplate reader (Fluoroskan Acent, Thermo Fisher Scientific Inc., Waltham, USA). For both assays the absorption/fluorescence signals of cellfree controls with different nanoparticle concentration were determined to prevent misinterpretations of the assays.

\subsection{Electric Cell-Substrate Impedance Sensing. Electric Cell-} Substrate Impedance Sensing (ECIS) measurements were performed to monitor the cellular behavior online. Therefore, cells were grown on 8W1E (8 well 1 electrode) ECIS slides (Applied BioPhysics, USA). Each of the eight wells contains an electrode covered with a gold film, used to apply an alternating current (AC) signal. Cell attachment, cell spreading, and cell morphological changes affect the measured electrode impedance which can be detected by ECIS Model 1600R (Applied BioPhysics, USA). Initially, each slide was equilibrated overnight with $400 \mu \mathrm{L}$ of standard culture medium. Then, the medium was removed and 125,000 cells (A549 cells or NIH-3T3 cells) in $400 \mu \mathrm{L}$ standard culture medium were seeded per well. One well remained cell-free as reference. After approximately $48 \mathrm{~h}$ the cells had grown to confluence and the impedance signal was stable. $\mathrm{ZnO}-\mathrm{NP}$ or $\mathrm{TiO}_{2}-\mathrm{NP}$ suspension in culture medium was added to the cells at least in duplicate at a concentration of the calculated half maximal inhibitory concentration $\left(\mathrm{IC}_{50}\right)$ value. In addition, at least two wells were filled with standard culture medium as control while nanoparticles to the cell-free well were added at the same concentration. The impedance signal was monitored during the entire time of the measurement.

2.8. Quantification of the Expression Levels of il-8 and hsp70 $m R N A$. The expression of $i l-8$ and $h s p 70$ genes was analyzed with quantitative real-time PCR (qPCR). In a T75 cultureflask 25,000 cells $/ \mathrm{cm}^{2}$ of A549 cells or NIH-3T3 cells were incubated at $37^{\circ} \mathrm{C}$ for $24 \mathrm{~h}$ before the cells were exposed to $\mathrm{ZnO}-\mathrm{NP}$ or $\mathrm{TiO}_{2}-\mathrm{NP}$ at a concentration of the $\mathrm{IC}_{50}$ value for $24 \mathrm{~h}$. NIH-3T3 cells were exposed to $20 \mu \mathrm{g} / \mathrm{mL} \mathrm{ZnO-}$ $\mathrm{NP} / \mathrm{TiO}_{2}-\mathrm{NP}$ and A549 cells to $40 \mu \mathrm{g} / \mathrm{mL}$. Afterwards, the total RNA was isolated by using the RNeasy Plus Mini Kit (QIAGEN, Hilden, Germany) following the manufacturer's instructions and the RNA concentration was measured at $260 \mathrm{~nm}$ by Nanodrop ND-1000 (Peqlab Biotechnologie $\mathrm{GmbH}$, Germany). For cDNA synthesis $2 \mu \mathrm{g}$ of RNA and $3 \mu \mathrm{L}$ oligo (dt) primers (poly d(T) 12-18 Primer, Roth, 
TABLE 1: Sequences of the primers used in qPCR.

\begin{tabular}{|c|c|c|c|c|}
\hline Gene name & $\begin{array}{c}\text { Gene bank accession } \\
\text { number (NCBI GenBank) }\end{array}$ & Location (bp) & $\begin{array}{l}\text { Expected size of PCR } \\
\text { amplicon (bp) }\end{array}$ & Sequence $\left(5^{\prime}-3^{\prime}\right)$ \\
\hline \multirow{2}{*}{$G A P D H$} & \multirow{2}{*}{ NM_002046.3 } & $880-900$ & \multirow{2}{*}{126} & F: AAGGTGGTGAAGCAGGCGTCG \\
\hline & & $1005-984$ & & R: AATGCCAGCCCCAGCGTCAAAG \\
\hline \multirow{2}{*}{$H P R T$} & \multirow{2}{*}{ NM_000194.2 } & $650-669$ & \multirow{2}{*}{267} & F: AAGCTTGCTGGTGAAAAGGA \\
\hline & & $897-916$ & & R: AAGCAGATGCCCACACAACT \\
\hline \multicolumn{5}{|l|}{ For A549 cells } \\
\hline \multirow{2}{*}{$I L-8$} & \multirow{2}{*}{ NM_000584.3 } & $221-240$ & \multirow{2}{*}{131} & F: CAGTTTTGCCAAGGAGTGCT \\
\hline & & $351-332$ & & R: AATTTCTGTGTTGGCGCAGT \\
\hline \multirow{2}{*}{ Hsp70 (HSPA1A) } & \multirow{2}{*}{ NM_005345.5 } & $2049-2068$ & \multirow{2}{*}{138} & F: GTGTAACCCCATCATCAGCG \\
\hline & & $2186-2166$ & & R: CAATCTTGGAAAGGCCCCTAA \\
\hline \multicolumn{5}{|l|}{ For NIH-3T3 cells } \\
\hline \multirow{2}{*}{$I L-8$} & \multirow{2}{*}{ NM_011339.2 } & $338-357$ & \multirow{2}{*}{110} & F: GAATTTCCACCGGCAATGAA \\
\hline & & $447-428$ & & R: TCCCGAATTGGAAAGGGAAA \\
\hline \multirow{2}{*}{ Hsp70 (HSPA1A) } & \multirow{2}{*}{ NM_010478.2 } & $2141-2161$ & \multirow{2}{*}{104} & F: CATCGAGGAGGTGGATTAGAG \\
\hline & & $2244-2225$ & & R: ACCTTGACAGTAATCGGTGC \\
\hline
\end{tabular}

Germany) in a total volume of $27 \mu \mathrm{L}$ (add with $\mathrm{ddH}_{2} \mathrm{O}$ ) were incubated at $65^{\circ} \mathrm{C}$ for $5 \mathrm{~min}$ and then held at $4^{\circ} \mathrm{C}$ for 1 min. Subsequently $8 \mu \mathrm{L}$ M-MLV RT $5 x$ Buffer (Promega, USA), $4 \mu \mathrm{L}$ dNTPs (dNTP set, Thermo Scientific, USA), and $1 \mu \mathrm{L}$ M-MLV Reverse Transcriptase (Promega, USA) were added and the mixture was incubated at $37^{\circ} \mathrm{C}$ for $1 \mathrm{~h}$. The qPCR was performed with a reaction volume of $25 \mu \mathrm{L}$, containing $0.5 \mu \mathrm{L}(0.2 \mu \mathrm{M})$ of each of the forward and reverse primers (see Table 1), $25 \mathrm{ng}$ cDNA template, and $12.5 \mu \mathrm{L}$ IQ SYBR Green Supermix (Bio-Rad, USA). The measurements were carried out on an iQ5 Multicolor Real-Time PCR Detection System (Bio-Rad, USA) and all samples were run in triplicate. In addition, the efficiency of each primer pair was determined using serial dilutions of the cDNA template. PCR reactions were performed at $95^{\circ} \mathrm{C}$ for $3 \mathrm{~min}$ followed by 40 cycles of $95^{\circ} \mathrm{C}$ for $10 \mathrm{sec}$ and of $57^{\circ} \mathrm{C}$ for $20 \mathrm{sec}$. The data (comparative threshold (ct) values) were analyzed using the Gene Expression Analysis for iCycler iQ Realtime PCR Detection System (Bio-Rad, USA). Glyceraldehyde 3-phosphate dehydrogenase (GAPDH) and hypoxanthineguanine phosphoribosyltransferase (HPRT) were used as endogenous control genes to normalize the expression of the target genes. Therefore, the expression levels of $h s p 70$ and of $i l-8$ are expressed as $n$-fold differences relative to the reference genes.

2.9. Data and Statistical Analysis. For the determination of the $\mathrm{IC}_{50}$ values dose response curves were fitted to the data obtained by the MTT or the CTB assay using OriginPro 8.5.0 SR1 (nonlinear curve fitting, growth/sigmoidal, DoseResp). The data shown are from at least three independent experiments triplicate $(n \geq 3)$. The ANOVA one-way analysis (OriginPro 8.5.0 SR1) was performed for statistical analysis and a significant effect was reported at ${ }^{*} p<0.05$.

\section{Results and Discussion}

3.1. Development of a Cellular Screening System. In our recent study we have constructed and validated a cell-based, hierarchical screening system in order to realize the analysis of a variety of nanoparticles and nanomaterials under defined and reproducible conditions (Figure 1). For this purpose, the scheme for biomaterials in tissue engineering published by Bruns et al. (2007) served as a template for our screening system for nanoparticles [22]. The idea of the screening system is that toxicity measurements are done during the course of nanomaterial development. The screening system is divided into a prescreening, a fine-screening, and a complexscreening (Figure 1). In the prescreening simple methods are used for all materials, whereas more complicated techniques are used for fine- and complex-screening which are applied only to selected materials. Especially in fine screening, the assays cover various impact areas on the cells.

After each screening step cells exhibiting a significant variation as compared to nontreated cells are identified ( $p<0.05$, ANOVA one way). Materials causing such significant variations are classified as cytotoxic and thus not further investigated and rejected, whereas the remaining nanomaterials are subjected to further analyses. Continuous communication (feedback) between the process chain and the screening system is essential in order to optimize nanoparticle development and associated safety testing. Feedback should be given with regard to the toxicity and the particle properties in order to select nanomaterials which are profitable and which should be further analyzed. Thus, the hierarchical structure facilitates making decisions as to which nanomaterials need complex, costly investigations or in vivo studies thus avoiding unnecessary testing of the remaining nanomaterials. Finally, only nanomaterials which pass 


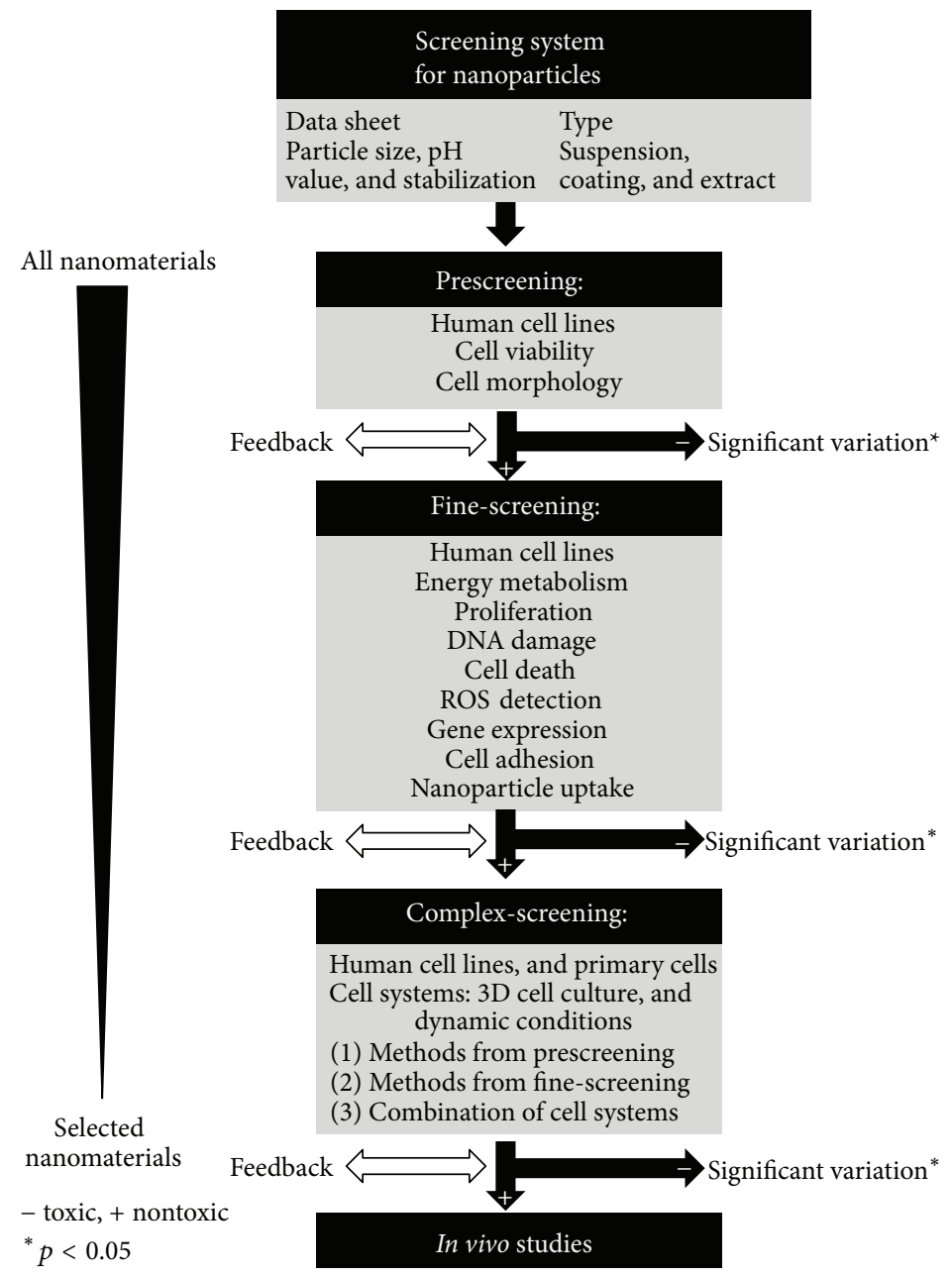

FIGURE 1: Hierarchical cell-based screening system for nanoparticle safety testing. The screening system is divided in prescreening, finescreening, and complex-screening and allows examining of a variety of nanoparticles during nanoproduct development. Prescreening is performed with all nanomaterials whereas complex cell systems are only applied to selected nanomaterials.

the whole screening system without significant side-effects can reach the application level. Thus, our screening system is highly efficient and cost minimizing and reduces animal studies.

Before nanoparticles or nanomaterials can be analyzed in the screening system, a thorough characterization is needed. Therefore, a data-sheet is required which provides information about the size, the surface modification, the zeta potential, the aqueous stability, and the sterilization methods.

According to the data-sheet information and the desired application of the nanomaterials, one specific type of nanoparticle testing is applicable such as suspension, coating, or extraction (detailed description is given below). For the evaluation of the nanoparticle screening system, two different, commonly used kinds of nanoparticles were selected: $\mathrm{ZnO}-\mathrm{NP}$ and $\mathrm{TiO}_{2}-\mathrm{NP}$. While the focus in this study has been on short-term nanoparticle exposure investigations, longterm conditions can also be tested in this complex-screening layout.

Concentrating on the desired application of the nanoparticles and on their potential incorporation into the human organism different cell lines were selected for the prescreening and for the fine-screening. The main absorption routes are via skin, via respiratory tract, and via gastrointestinal tract [1]. The skin, being the largest organ [1], provides a large target surface for nanoparticles. Recent studies have reported the penetration of nanoparticles [1] through the skin tissue which means investigations of in vitro skin test systems are needed. In addition, nanoparticles can be inhaled and can be absorbed by pulmonary alveoli $[1,8]$. Moreover, via the gastrointestinal tract nanoparticles can reach the liver and accumulate there in [1]. With regard to the described absorption routes, a matrix of relevant cell lines is required to identify cytotoxic effects of nanoparticles in vitro because various cell lines display different sensitivities and cell responses [1,23].

To avoid cell-type specific behavior it is important to use different cell lines. Therefore, commonly used cell lines such as A549 cells (lung model) and NIH-3T3 cells (skin model) have been applied here. The use of mammalian cell lines in the screening system has the advantage that they provide reproducible results as cells are uniform, standardized, and well characterized. Thus, cell lines provide 
the first evidence concerning the toxicity of the nanomaterials.

However, using standardized cell lines bears the disadvantage that their cell behavior cannot be easily transferred to in vivo conditions because they are often immortalized or isolated from tumors [6]. In addition, the proliferation rate of immortalized cell lines is often higher than that of in vivo cells [6]. Therefore, in the screening system primary cells and complex cell systems are examined to better mimic real tissue conditions in a human organism. These cell systems are three-dimensional (3D) cell cultures where cells can develop more in vivo-like cell-cell interactions and an extracellular matrix [24, 25]. Secondly, dynamic conditions are performed to mimic, for instance, the blood stream. Both cell systems can finally be combined for a higher complexity and to perform long-term exposure analysis. Since these models require much more complex settings, they are used only with selected nanomaterials in complex-screening.

\subsection{Prescreening: Morphology Studies and Comparison of \\ Nanoparticle Suspensions, Coatings, and Extract Medium}

3.2.1. Morphology Studies of A549 Cells and NIH-3T3 Cells Exposed to $\mathrm{ZnO}-\mathrm{NP}$ and $\mathrm{TiO}_{2}-\mathrm{NP}$ in $2 \mathrm{D}$ and $3 \mathrm{D}$ Cell Cultures. For in vitro studies $2 \mathrm{D}$ cell cultures are needed in the prescreening because they allow high-throughput screening. Thus, different nanoparticles, nanoparticle concentrations, and various cell types can be tested in parallel. The prescreening reduces the huge amount of nanomaterials obtained from the process chain to a more manageable number. Decisions have to be made concerning the question which nanomaterial requires further investigation in the fine-screening or complex-screening. The impact of the cell viability after nanoparticle exposure indicating cytotoxic effects is analyzed with commonly used assays such as the MTT, the CTB, or the WST-1 (4-[3-(4-iodophenyl)-2-(4-nitrophenyl)-2H5-tetrazolio]-1,3-benzene disulfonate) assay. With all three assays, comparable results can be produced which only differ in their sensitivity. Besides these viability measurements, morphology studies are applied in the prescreening. Cell morphology studies are important to support the results obtained with cytotoxicity assays, especially with regard to potential interference by the nanoparticles on the assay compounds. Some harmful effects can be identified via cell morphology changes, so in these cases false-positive results may be detected.

To validate the significance of cell morphology studies for screening cytotoxic effects of nanoparticles, A549 and NIH$3 \mathrm{~T} 3$ cells were treated with $\mathrm{ZnO}-\mathrm{NP}$ or $\mathrm{TiO}_{2}-\mathrm{NP}$, respectively. In addition, the cells were grown in $2 \mathrm{D}$ as well as in $3 \mathrm{D}$. For 3D cell cultures the cells were encapsulated in a hydrogel. The cell morphology of nontreated and treated cells was analyzed. The specific $\mathrm{IC}_{50}$ value calculated from the viability results for both cell lines and with both cell systems was displayed. In Figure 2 the cell morphology of NIH-3T3 (c) and A549 cells (g) grown in 2D and treated with $\mathrm{ZnO}-\mathrm{NP}$ is shown. In the standard culture media the NIH-3t3 cells exhibit their characteristic contact arms to their neighboring cells (Figures 2(a) and 2(b)). ZnO-NP treated NIH-3T3 cells at the $\mathrm{IC}_{50}$ value changed their morphology turning smaller and rounder, characteristic of dead cells. At higher nanoparticle concentrations they became detached from the surface. For A549 cells grown in 2D, the control cells had a triangular shape and became round when $\mathrm{ZnO}-\mathrm{NP}$ were added ( $\mathrm{IC}_{50}$ value) (Figure 2(e)). In 3D the NIH-3T3 cells displayed the same changes as observed in the $2 \mathrm{D}$ cell culture (Figure 2(b)). In the hydrogel NIH-3T3 cells are highly networked (Figure 2(b)). At the $\mathrm{IC}_{50}$ value the cells turned round (Figure 2(d)). On the contrary, A549 cells grown in the hydrogel were round in the standard culture media as well as in the $\mathrm{ZnO}-\mathrm{NP}$ treated media (Figures 2(f) and 2(h)). Thus, no significant differences in their morphology could be revealed. For $\mathrm{TiO}_{2}-\mathrm{NP}$ no reduction in the viability was determined and both cells lines did not show any morphology changes (data not shown).

In summary, the morphology studies should be regarded as an important tool in the nanoparticle safety screening system. In some cases, however, the viability assay is not sufficient to prescreen the nanoparticles accurately. In this context, for in vitro drug testing Quent et al. have reported an overestimation of the viability of daunorubicin-treated cells determined by the MTT assay [4]. The morphology study clearly displays the release of detached cells indicating cell death whereas the MTT was still reduced in the cells [4]. In our study, ZnO-NP morphology changes of NIH-3T3 cells could be observed in $2 \mathrm{D}$ as well as in the 3D hydrogels. Also for A549 cells grown in 2D the toxic effect of ZnO-NP was determined by the cell morphology studies. However, for A549 cells growing in hydrogel this method failed to identify toxic effects. Here, no changes in the morphology of the A549 cells after adding ZnO-NP to the culture were observed while the cell viability assay showed a significant reduction at this concentration (Table 1). Furthermore, different 3D cell culture models based on cell aggregation (spheroids), cell encapsulation (hydrogel), and cell adhesion on scaffolds are currently used to mimic a 3D environment. In particular, the scaffold model hinders morphology studies as scaffolds are not transparent. In conclusion, morphology studies can support other cytotoxic assays while they can only detect specific impacts of nanoparticle exposure.

3.2.2. Cell Viability Measurements of A549 Cells and NIH$3 \mathrm{~T} 3$ Cells Exposed to $\mathrm{ZnO}-\mathrm{NP}$ and $\mathrm{TiO}_{2}-\mathrm{NP}$ in Suspension, in Extract Medium, or on Coatings. For in vitro nanoparticle safety testing, the methodological challenge is the preparation of stable, aqueous, physiological nanoparticle suspensions because nanoparticles often agglomerate in biological media. As reported by Jones and Grainger (2009) these nanoparticle aggregations can affect several nanoparticle properties such as size and cellular uptake [6]. Currently, different dispersion protocols and various biocompatible stabilizers are being examined for generating stable nanoparticle suspensions $[7,26]$. Protocols have thus been developed for the dispersion of nanoparticles in FCS using various centrifugation steps [7], in culture media [7] or in an aqueous suspension [26]. Only with gum arabic as a stabilizer 


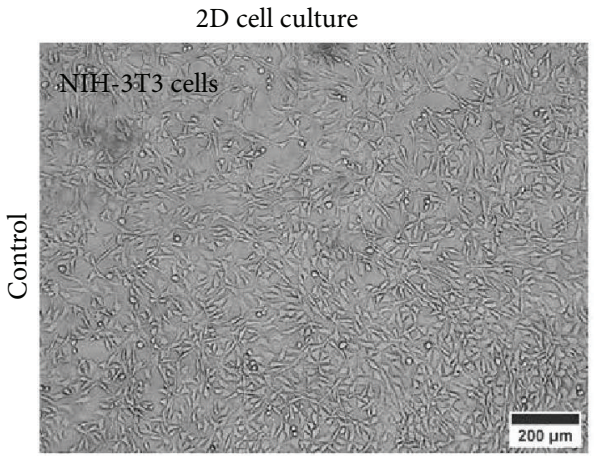

(a)

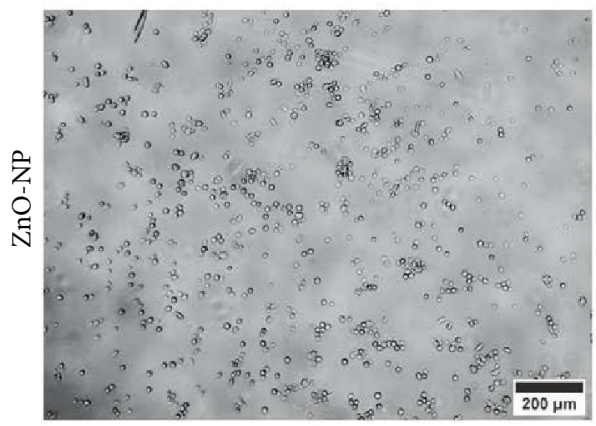

(c)

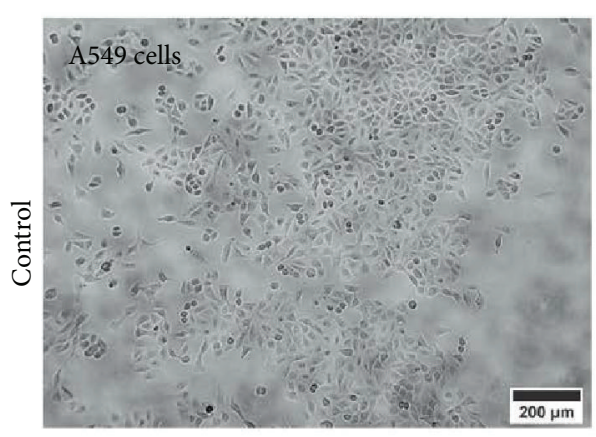

(e)

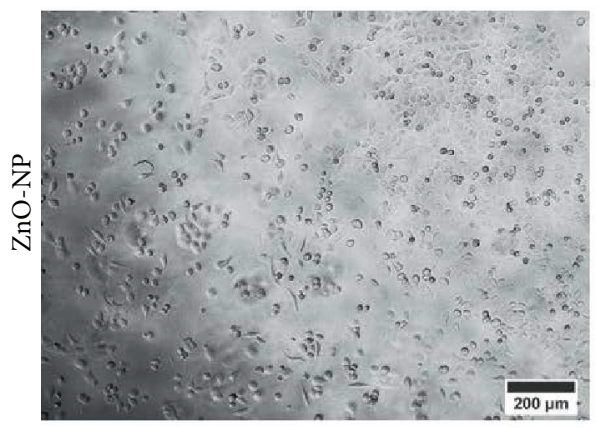

(g)

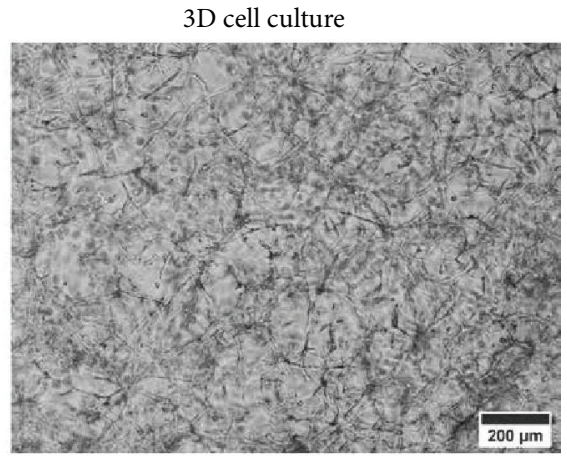

(b)

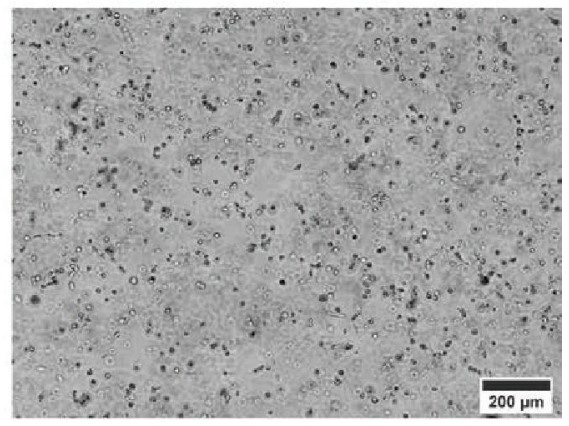

(d)

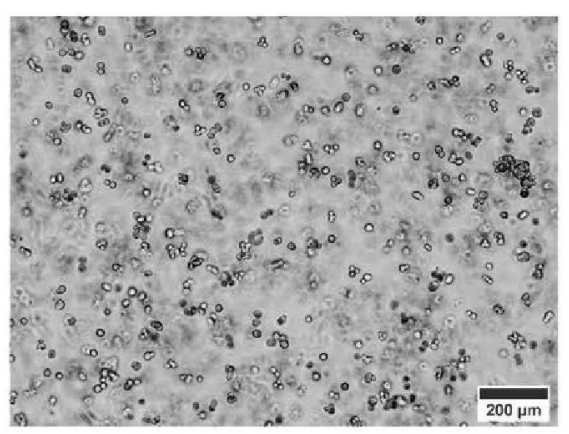

(f)

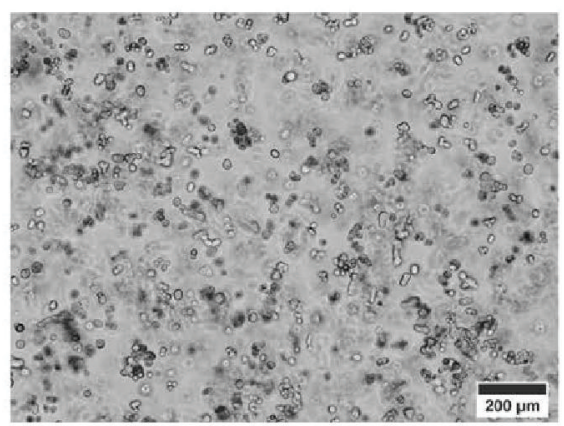

(h)

Figure 2: Morphology studies of NIH-3T3 cells (a-d) and A549 cells (e-h) grown on 2D monolayers (a, c, e, g) or encapsulated in a hydrogel (3D cell culture) (b, d, f, h). NIH-3T3 cells were cultivated in standard culture medium (a, b) or were treated with $10 \mu \mathrm{g} / \mathrm{mL} \mathrm{ZnO-NP} \mathrm{in} 2 \mathrm{D}$ (c) and in 3D (d). For A549 cells $40 \mu \mathrm{g} / \mathrm{mL} \mathrm{ZnO}-\mathrm{NP}$ were added in 2D (g) and $300 \mu \mathrm{g} / \mathrm{mL} \mathrm{ZnO-NP}$ in 3D (h). The A549 control cells cultivated in standard culture medium were displayed in (e) and (f). Morphology changes after ZnO-NP exposure were observed in $2 \mathrm{D}$ for both cell lines whereas in 3D effects were only determined for NIH-3T3 cells. 

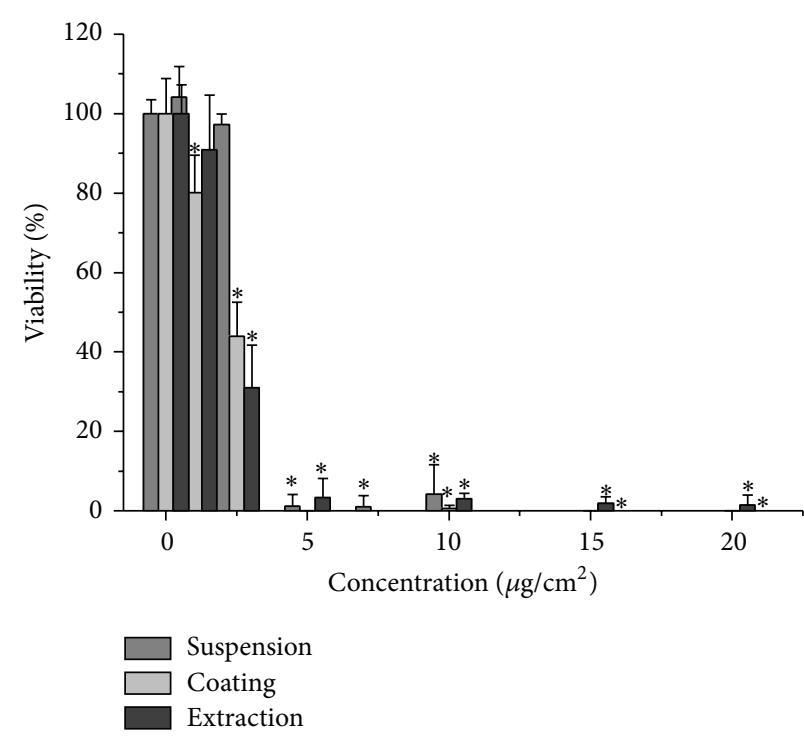

(a) NIH-3T3 cells

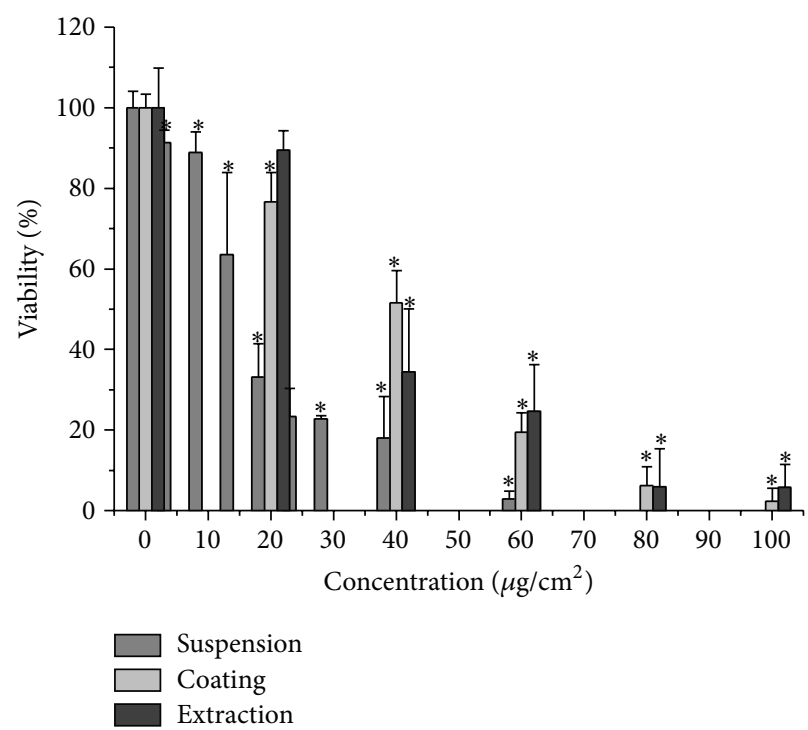

(b) A549 cells

Figure 3: Viability of NIH-3T3 cells (a) and A549 cells (b) after ZnO-NP exposure determined with the MTT assay. The cells were treated with nanoparticle suspension, coating, or extract medium. The signals of untreated cells were set as $100 \%$. Data points are means \pm SD for $n \geq 3 .{ }^{*} p<0.05$.

the $\mathrm{ZnO}-\mathrm{NP}$ suspension was found to be stable for more than five days [26]. In this study alternative in vitro techniques were developed and validated to avoid the described problems with nanoparticle suspensions. We studied whether similar cell viability results can be obtained with nanoparticle suspensions, extract medium, and coatings. For this purpose both cell lines were seeded on nanoparticle coatings and viability measurements were carried out. Additionally, extract media from $\mathrm{TiO}_{2}-\mathrm{NP}$ and $\mathrm{ZnO}-\mathrm{NP}$ coatings, respectively, were prepared according to the ISO 10993-12:2012 standard for medical devices and subsequently used for the treatment of the cells [20]. Thereby, we wanted to monitor whether nanoparticles are dissolved from the coatings thus influencing the viability of the cells.

For $\mathrm{TiO}_{2}$-NP no significant reduction in the viability of either cell line tested was observed for all three methods (see supporting information, Figure 8; see Supplementary Material available online at http://dx.doi.org/10.1155/2015/691069). On the other hand, the viability of the cells was reduced by $\mathrm{ZnO}-\mathrm{NP}$ in a dose-dependent manner. In Figure 3 the viability of $\mathrm{ZnO}-\mathrm{NP}$ suspensions, coatings, and extract medium upon exposure to NIH-3T3 and to A549 cells is displayed. In addition, in Table 2 the $\mathrm{IC}_{50}$ value of the viability measurements are summarized.

For $\mathrm{ZnO}-\mathrm{NP}$ toxic effects were detected with all three methods and with both cell lines performing the MTT assay. NIH-3T3 cells were found to be more sensitive to ZnO-NP than A549 cells; thus different cell lines apparently show different sensitivity to nanoparticles. The NIH-3T3 cells exhibited the same $\mathrm{IC}_{50}$ value for $\mathrm{ZnO}-\mathrm{NP}$ suspensions, coatings, and extract medium. On the contrary, the $\mathrm{IC}_{50}$ value determined for $\mathrm{ZnO}-\mathrm{NP}$ suspensions in A549 cells was found to be half of the $\mathrm{IC}_{50}$ value determined with
TABLE 2: Calculated $\mathrm{IC}_{50}$ value of NIH-3T3 cells and A549 cells treated with $\mathrm{ZnO}-\mathrm{NP}$ suspensions, coatings, or extract medium (MTT assay). For A549 cells the $\mathrm{IC}_{50}$ value for nanoparticle suspensions is twice lower as compared with the respective coatings. Data points are mean \pm SD for $n \geq 3$.

\begin{tabular}{lcc}
\hline & \multicolumn{2}{c}{$\mathrm{IC}_{50}$ value $\left[\mu \mathrm{g} / \mathrm{cm}^{2}\right]$} \\
& $\mathrm{NIH}-3 \mathrm{~T} 3$ cells & A549 cells \\
\hline Suspension & $3 \pm 1$ & $18 \pm 5$ \\
Coating & $2 \pm 1$ & $31 \pm 8$ \\
Extract medium & $2 \pm 2$ & $30 \pm 8$ \\
\hline
\end{tabular}

the coating experiments. Therefore, instead of suspension testing for the identification of toxic nanoparticles, coating analysis can be a good alternative, especially for nanoparticles which agglomerate in standard culture media. For the coating and extract medium results no differences in the $\mathrm{IC}_{50}$ values were observed for either cell line. Thus, the determined reduction in the cell viability is apparently caused by the release of $\mathrm{ZnO}-\mathrm{NP}$ from the coating. Our results clearly demonstrate that $\mathrm{ZnO}-\mathrm{NP}$ exposure induces a decrease of the cell viability indicating toxic effects.

Obviously, nanoparticle effects to human cell lines can be investigated either with stable suspensions, with coatings, or with extract medium. The choice of strategy depends on the nanoparticle properties as well as on the desired application of the nanoproduct. While for some nanoparticles a stable aqueous suspension in the cell culture medium can be produced, other nanoparticles agglomerate under these conditions. When evaluating the potential risk of nanoparticles to human beings, it should be considered that nanoparticles often may not reach the human organism as individual nanoparticles but rather as nanoparticle agglomerates. 
In in vitro studies, proteins present in the media often adsorb to the nanoparticles [2] thus affecting the cell response of the nanoparticle treatment. The same effect may take place in the human organism. Consequently, nanoparticle agglomerate analysis can make sense, for example, to predict the in vivo cell behavior. On the contrary, for the in vitro investigation of nanoparticle effects in the respiratory tract, stable nanoparticle suspensions are required. Inhaled particles with diameters below $2.5 \mu \mathrm{m}$ can reach the pulmonary alveoli where they can be absorbed [8]. For any nanoparticle test system it is therefore important to consider the relevance for human health effects [27].

As an alternative technique for nanoparticle in vitro testing we performed the so-called coating method. However, the proliferation rate of adherent cells can be affected by nanostructured surfaces. Several studies have demonstrated that the surface roughness of the cell culture plates influences the cellular behavior [28-30]. Therefore, the stability of certain nanoparticle coatings (nanomaterials and nanocomposites) and the effect of potentially solved nanoparticles to the human organism may be more relevant. Thus, the preparation of extract media is the chosen strategy for certain nanomaterial applications such as for medical devices, window glasses, or sanitation. Comparable with our extract experiments, Paddle-Ledinek et al. (2006) have used this method before to test wound dressings coated with nanoparticles [31]. In the present study, it could be shown that nonstable nanoparticle coatings require particular care during the testing process. Hence, measurements of the toxic effect of $\mathrm{ZnO}-\mathrm{NP}$ with suspensions, with coatings, and with the extraction method demonstrated that extract testing is an alternative indirect method to investigate the cytotoxicity of nanomaterials.

In summary, the nanoparticle screening system introduced here is capable of analyzing suspensions, coatings, as well as coating extractions regarding the respective application of the nanomaterials. Moreover, the analysis of the extract also monitors the stability of the coating.

\subsection{Fine-Screening: Gene Expression Analysis and ECIS Mea-} surements of A549 Cells and NIH-3T3 Cells Exposed to ZnO$\mathrm{NP}$ and $\mathrm{TiO}_{2}-\mathrm{NP}$. Following the prescreening assays, finescreening tests were performed to provide higher sensitivity and to yield detailed information concerning the cell responses induced by the nanoparticle exposure. To avoid potential misinterpretations resulting from, for example, possible interference of nanoparticles with the assay components, different methods based on fluorescence or luminescence are used here in the fine-screening. Additionally, several positive and negative controls are needed. Moreover, for an accurate in vitro nanoparticle fine-screening, various biological effects of the nanoparticles were analyzed. The energy metabolism in the cells can, for example, be investigated with adenosine triphosphate (ATP). For cell death analysis, the release of lactate dehydrogenase (LDH) indicates necrosis and the caspase activity or the annexin V-FITC/PI assay indicating apoptosis can be performed. Changes in the proliferation rate of the cells can be detected with the bromodeoxyuridine (BrdU) assay which is based on the integration of BrdU, a chemical analogue of the nucleoside thymidine. BrdU can be detected by labeled antibodies and indicates the proliferation rate of the cell. Moreover, DNA damage in cells caused by the exposure to nanoparticles can be observed by the alkaline microelectrophoresis (comet assay). Also, the generation of reactive oxygen species (ROS) induced by nanoparticles can be determined, thus demonstrating stress for the cells. A commonly used assay for the ROS detection is the DCF assay. In addition, nanoparticles may also affect the gene regulation, so the expression of selected marker genes can be quantified using real-time PCR or microarray analysis. Molecular markers can, for instance, be mitosis markers, heat-shock proteins, interleukins, or apoptosis markers. While all the described methods are endpoint assays, the Electric CellSubstrate Impedance Sensing (ECIS) measurement provides online data. Cell morphology changes such as cell rounding or surface detachment can be detected immediately after the addition of nanoparticles [2]. Moreover, no additional compounds are required for this alternative technique, minimizing false-positive results [32].

In our study, we investigated the effects of $\mathrm{ZnO}-\mathrm{NP}$ and $\mathrm{TiO}_{2}-\mathrm{NP}$ on gene expression using real-time PCR analysis. We selected two established biomarkers: il-8 indicating inflammation $[33,34]$ and $h s p 70$ indicating oxidative stress responses $[35,36]$. In NIH-3t3 cells (Figure 4(a)) as well as in A549 cells (Figure 4(b)), the il-8 mRNA level was increased when cells were exposed to $\mathrm{ZnO}$-NP. Furthermore, $\mathrm{ZnO}$ NP induced hsp70 expression in A549 cells (Figure 4(b)). On the contrary, exposing NIH-3T3 cells and A549 cells to $\mathrm{TiO}_{2}$-NP did not lead to higher levels of the investigated biomarkers. The real-time PCR results clearly demonstrated that $\mathrm{ZnO}-\mathrm{NP}$ induce inflammation in both investigated cell lines and additionally oxidative stress in A549 cells. Several studies confirmed our investigation. In human bronchial epithelial cells, for example, $\mathrm{ZnO}-\mathrm{NP}$ exposure increased the expression of il-8 mRNA [33] as well as the protein level [33, 37]. Also, il-8 mRNA secretion has been used for identifying cytotoxic effects of other nanoparticles, such as carbon nanotubes and polystyrene nanoparticles [38]. Exposure of $\mathrm{TiO}_{2}$-NP to keratinocytes [7], human monocytes, and lung epithelial cells [36] did not cause inflammation. Furthermore, for $\mathrm{TiO}_{2}-\mathrm{NP}$ an increase of the il-8 gene expression in A549 cells was only achieved at unrealistically high concentration $\left(400 \mu \mathrm{g} / \mathrm{cm}^{2}\right)$ with regard to in vivo conditions [34]. However, in vivo studies with mice demonstrated that $\mathrm{TiO}_{2}-\mathrm{NP}$ induce increased levels of several interleukins such as il-8 mRNA $[39,40]$.

The second chosen biomarker, hsp70, was already validated for investigation of the effect of several nanoparticles. Hsp70's virtues include that it is a very sensitive biomarker for cellular stress responses, it is well characterized [41, 42], and it precludes false protein-folding [43]. The toxic effect of silver nanoparticles was determined in vivo by an increased level of hsp70 mRNA [44, 45] and of Hsp70 protein [41] indicating oxidative stress. Furthermore, Cu-NP [42], carbon-black nanoparticles [46], and CdSe/ZnS nanoparticles [47] induced $h s p 70$ expression. While in our study ZnO-NP exposure leads to a higher $h s p 70$ expression in A549 cells, this effect was not observed for NIH-3T3 cells. According to Chen et al. (2012), NIH-3T3 cells exhibited a lower heat-shock response than 


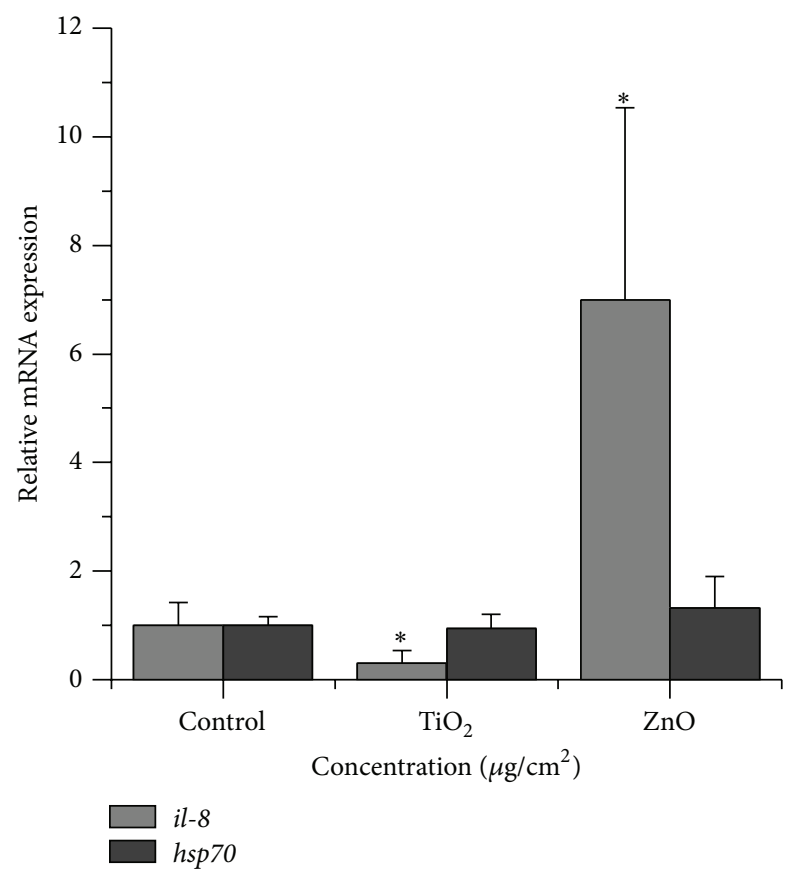

(a)

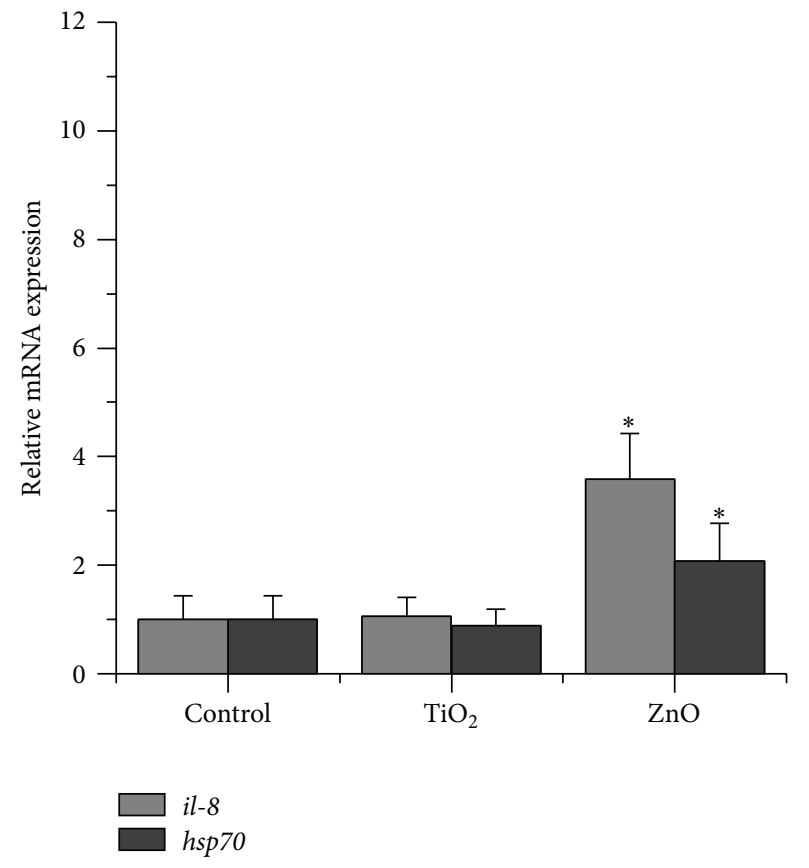

(b)

FIgure 4: Relative mRNA expression of il-8 and hsp70 from NIH-3T3 cells (a) and A549 cells (b) upon treatment with $\mathrm{ZnO}^{-\mathrm{NP}}$ or TiO 2 -NP

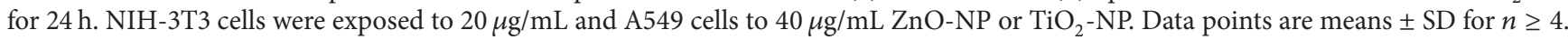
Significant differences versus the control group are indicated in the figure (ANOVA, one way). ${ }^{*} p<0.05$.

other cell lines; thus the sensitivity to nanoparticle response detection was reduced [43]. In addition, different cell lines revealed a variance in their exposure time-course response [43]. For $\mathrm{TiO}_{2}-\mathrm{NP}$ no significant changes of $h s p 70$ expression relative to the control cells were observed for Thp-1 cells (human monocytes) or for NCI-H292 cells (human lung epithelial cells) [36] but not for other cell lines such as NIH$3 \mathrm{~T} 3$ cells or HepG2 cells [43]. On the contrary, the hsp70 expression in mice (in vivo) was downregulated after $\mathrm{TiO}_{2}$ NP exposure [39, 40]. Presumably, hsp70 reduction could indicate a detoxification process of the cells [40].

ECIS measurements were used for the online monitoring of nanoparticle effects in the cells. Instead of endpoint measurements, cellular response to nanoparticle addition can be observed directly by this method and no additional dye is needed. Thus, interference of assay compounds with nanoparticles can be minimized. The results of the impedance measurements of NIH-3T3 cells (Figure 5(a)) and of A549 cells (Figure 5(c)) cultivated with $\mathrm{ZnO}-\mathrm{NP}$ were compared with the control cells.

After addition of $\mathrm{ZnO}-\mathrm{NP}$ to the cells, the impedance signal dropped immediately for the NIH-3T3 cells. Interestingly, for A549 cells the impedance signal increased after $\mathrm{ZnO}-\mathrm{NP}$ addition during the first $10 \mathrm{~h}$ before it decreased again. The cells treated with $\mathrm{ZnO}-\mathrm{NP}$ lost their cell-cell interaction, became smaller, and detached from the surface. The decrease of the impedance signal indicates the cell death; thus $\mathrm{ZnO}-\mathrm{NP}$ exhibited a toxic effect to the cells. The slight increase of the impedance signal for A549 cells after ZnO-NP addition had been already reported by Seiffert et al. (2012)
[32]. Such an effect cannot be explained with proliferation as A549 cells have doubling times of $24 \mathrm{~h}$; thus another cellular response must have occurred [32]. For $\mathrm{TiO}_{2}-\mathrm{NP}$ no changes in the impedance signal were revealed with both cell lines (Figures 5(b) and 5(d)) indicating no cellular changes. Also, the impedance of a cell-free control did not change. Thus, the nanoparticles themselves did not affect the impedance signal.

ECIS measurements have previously been used for cytotoxicity analysis of nanoparticles. A significant decrease in the impedance signal indicating cytotoxicity was determined for $\mathrm{ZnO}-\mathrm{NP}$ as well as for CuO-NP but not for $\mathrm{TiO}_{2}-\mathrm{NP}$ [32]. Furthermore, the calculated $\mathrm{IC}_{50}$ value determined with the viability assay was found to be comparable with the one determined by the cell-impedance measurements after $24 \mathrm{~h}$ [32]. For anatase $\mathrm{TiO}_{2}-\mathrm{NP}$ no significant cytotoxic effect was observed $[48,49]$ and for rutile $\mathrm{TiO}_{2}-\mathrm{NP}$ it was observed only at high concentrations $\left(\mathrm{IC}_{50}\right.$ value $\left.>200 \mu \mathrm{g} / \mathrm{mL}\right)[48,50]$. Therefore, the effect of $\mathrm{TiO}_{2}$-NP on the cellular behavior appears to be dependent on the particle size as well as on the shape.

In our study during the fine-screening stage, $\mathrm{TiO}_{2}-\mathrm{NP}$ were not found to cause a significant variation either in the gene expression analysis or in the ECIS measurements. Thus, these particles should be further analyzed in the complexscreening mode.

3.4. Complex-Screening: Comparison of Cell Viability of A549 Cells and of NIH-3T3 Cells Exposed to $\mathrm{ZnO}-\mathrm{NP}$ and $\mathrm{TiO}_{2}-\mathrm{NP}$ in $2 D$ and in Different $3 D$ Cell Culture Models. The complexscreening is performed for the remaining nanomaterials not 


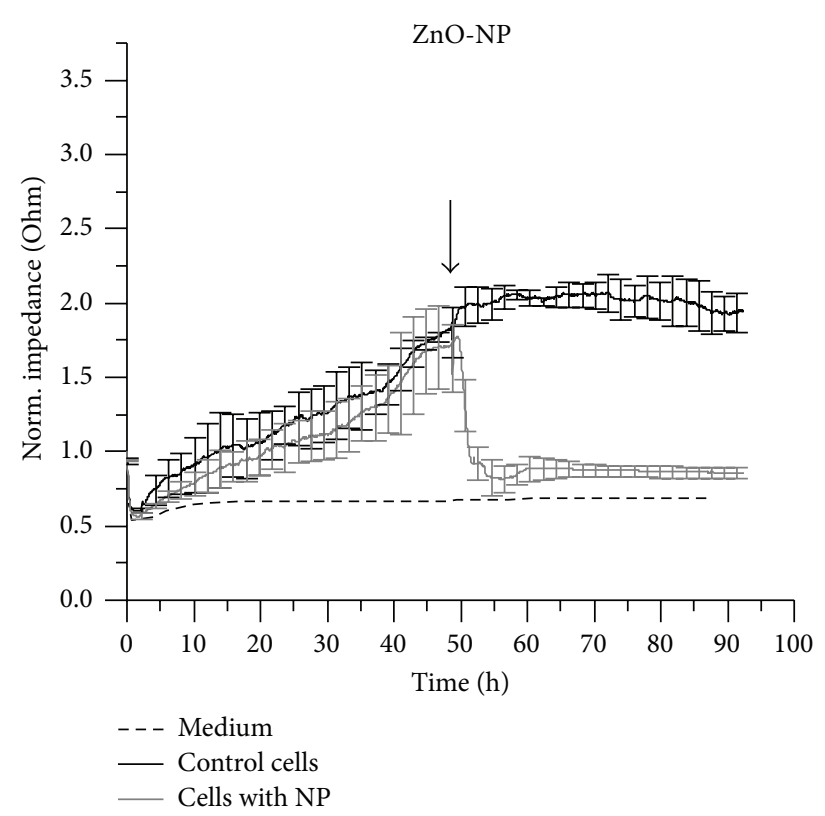

(a) NIH-3T3 cells

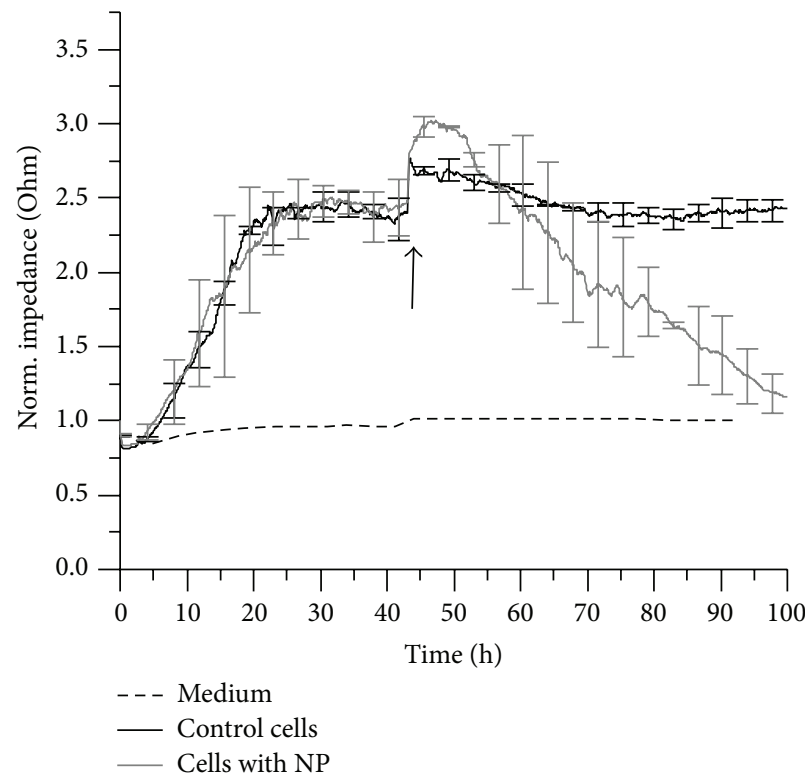

(c) A549 cells

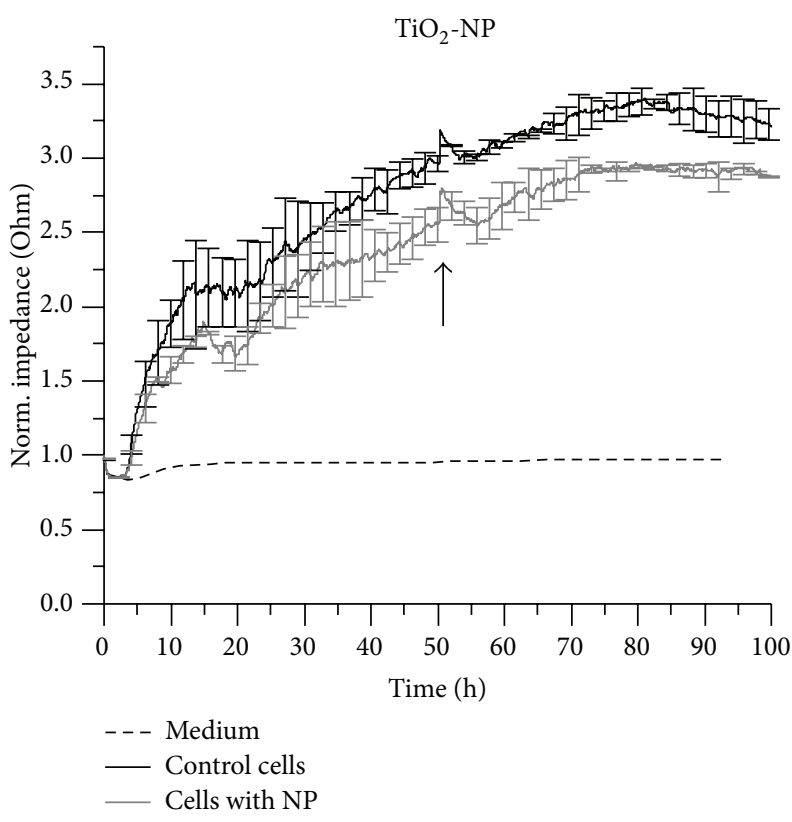

(b) NIH-3T3 cells

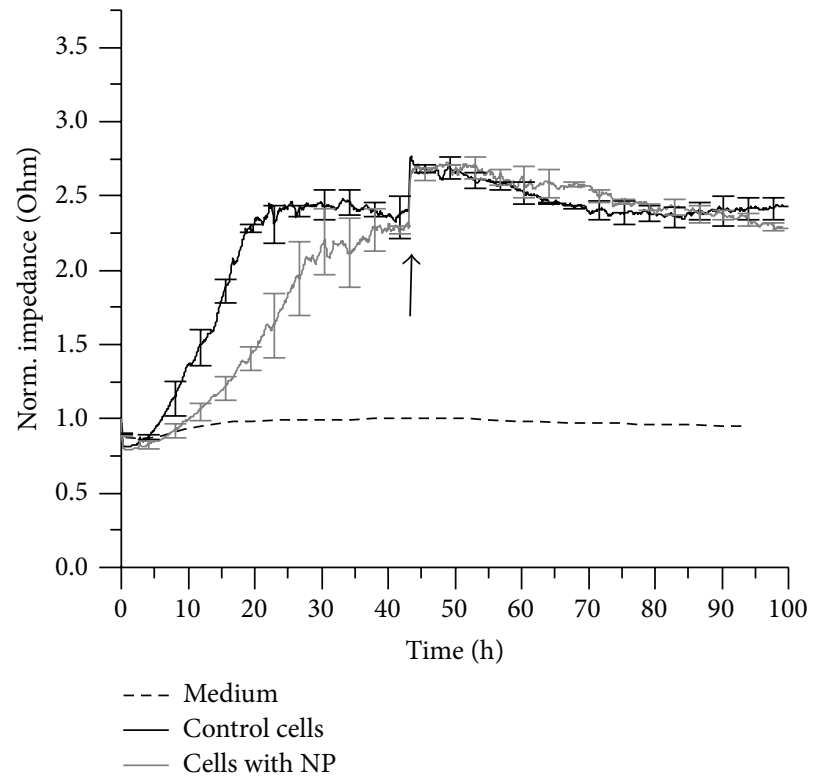

(d) A549 cells

Figure 5: Electric Cell-Substrate Impedance Sensing of NIH-3T3 cells (a, b) and A549 cells (c, d) to monitor nanoparticle toxicity. The cells were grown to confluence before nanoparticle exposure. Dynamic changes in the impedance signal of NIH-3T3 cells to 0 and $20 \mu \mathrm{g} / \mathrm{mL}$ suspensions of $\mathrm{ZnO}-\mathrm{NP}$ (a) or $\mathrm{TiO}_{2}-\mathrm{NP}$ (b) are displayed. For A549 cells the effect of $40 \mu \mathrm{g} / \mathrm{mL}$ of $\mathrm{ZnO}-\mathrm{NP}$ (c) and $\mathrm{TiO}{ }_{2}-\mathrm{NP}$ (d) was investigated. Cell-free medium with nanoparticles was used as reference. The measurements were performed with a $16 \mathrm{kHz}$ ac source. The time point for nanoparticle addition is indicated with the black arrow. Data points are means \pm SD for $n \geq 3$.

exhibiting any clear toxic effects during the fine-screening to apply more extensive in vitro methods. As currently used 2D cell culture models have several limitations [25,51], 3D cell culture systems are employed here. The cells were grown in a more physiological cell environment to better predict the cellular behavior in the organism. The 3D cell culture exhibits a higher complexity compared to the conventional $2 \mathrm{D}$ cell culture and is more expensive. Currently, different models have been developed to enable in vitro 3D cell growth such as cell spheroids, cell encapsulation in hydrogel [52], or cell adhesion on scaffolds. Secondly, the bloodstream can be mimicked by cells growing under continuous flow conditions (2D cell culture). Here, a shear stress is applied to the cells during nanoparticle exposure. Therefore, to realize both aspects in the complex-screening, it is divided into three sections (Figure 1). In the first section the methods used in 
the prescreening are performed either on a $3 \mathrm{D}$ cell culture model or under continuous flow conditions. Afterwards in Section 2, the methods of the fine-screening are performed. Finally, after the nanoparticles have been tested separately in the cell culture systems a combination of 3D cell culture and continuous flow conditions should be performed (Section 3 ). In contrast to the previously described methods, long-term exposure analysis can also be carried out hereby. These experiments provide more relevant results, so in vivo studies should follow when no significant variation is detected. Thus, the complex-screening can bridge the gap between the cellbased in vitro testing and the in vivo studies, thereby reducing the amount of required animal studies.

In our study we compared different $3 \mathrm{D}$ cell culture models and their applicability for the investigation of nanoparticle toxicity. NIH-3T3 cells and A549 cells were seeded on collagen scaffolds or were encapsulated in a hydrogel. The scaffold model as well as the encapsulation of cells in the hydrogel was developed within the present study. For both of these 3D cell culture models we have optimized parts of the procedure like the cell density and incubation for cell growth and the assay performance. The composition of the semisynthetic PEG-fibrinogen-based hydrogel mix was tuned to create a defined structure and to enable cell growth. The cells were treated with different concentrations of $\mathrm{ZnO}-\mathrm{NP}$ or $\mathrm{TiO}_{2}-\mathrm{NP}$ and the viability of the cells was determined. In addition, the two 3D cell culture models were compared with the alreadypublished data for cell spheroids [19]. As described above, not all assays can be combined with all cell culture systems. The viability assays differ in the solubility of the detectiondye. Whereas the MTT assay generates an insoluble product, the reagent used in the CTB assay is soluble. In our study we preferred the CTB assay to measure the viability of the cells grown in the hydrogel because no additional solution step was needed for detection. On the other hand, for the cells grown on the collagen scaffold, diffusion limitations of the reactive dye may affect the results. To avoid only cells on the outer scaffold surface metabolizing the dye, we used the MTT assay instead. Here, the formed blue formazan was trapped in the cells once MTT was metabolized. Thus, the MTT was able to reach the cells inside the scaffolds as well and the viability of all living cells can be revealed. For a better comparison of the $3 \mathrm{D}$ cell culture results, both assays were performed with the 2D cell culture as well. Figure 6 displays the viability of both cell lines after $\mathrm{ZnO}-\mathrm{NP}$ exposure determined with the CTB assay or the MTT assay. The cells were encapsulated in hydrogel, seeded on scaffolds, or cultured on $2 \mathrm{D}$ monolayers.

In Table 3 the calculated $\mathrm{IC}_{50}$ values for $\mathrm{ZnO}-\mathrm{NP}$ in the $2 \mathrm{D}$ cell culture as well as in the $3 \mathrm{D}$ cell culture models are summarized for A549 and for NIH-3T3 cells. Additionally, the spheroid results from our previous study are listed to allow a comparison of all three 3D cell culture models [19]. Again $\mathrm{ZnO}-\mathrm{NP}$ reduced the viability of the cells in a dosedependent manner in the $2 \mathrm{D}$ as well as in the $3 \mathrm{D}$ cell cultures. The results of the two different cell viability assays did not show a significant difference for the $2 \mathrm{D}$ cell culture. The choice of the viability assay for cells growing in $3 \mathrm{D}$ is dependent on the used $3 \mathrm{D}$ model. For the $3 \mathrm{D}$ scaffold
TABLE 3: Comparison of calculated $\mathrm{IC}_{50}$ values for $\mathrm{ZnO}-\mathrm{NP}$ of $2 \mathrm{D}$ cell culture and different 3D cell culture models. NIH-3T3 cells and A549 cells were attached on collagen scaffolds, encapsulated in hydrogel or aggregated in spheroids to grow in $3 \mathrm{D}$. After exposure to $\mathrm{ZnO}-\mathrm{NP}$ the viability of the cells was determined using either the MTT assay or the CTB assay. Values are means \pm SD for $n \geq 3$. * Data were already published by Sambale et al. 2015 [19].

\begin{tabular}{lccc}
\hline & \multirow{2}{*}{ Viability assay } & \multicolumn{2}{c}{$\mathrm{IC}_{50}$ value $[\mu \mathrm{g} / \mathrm{mL}]$} \\
& MIH-3T3 cells & A549 cells \\
\hline 2D & MTT & $10 \pm 3$ & $58 \pm 16$ \\
2D* & CTB & $15 \pm 6$ & $54 \pm 12$ \\
3D scaffold & MTT & $11 \pm 2$ & $75 \pm 18$ \\
3D hydrogel & CTB & $7 \pm 3$ & $328 \pm 13$ \\
3D spheroids* & CTB & $9 \pm 1$ & $42 \pm 13$ \\
\hline
\end{tabular}

model the MTT assay and for 3D hydrogel the CTB assay gave reliable results. According to the $\mathrm{IC}_{50}$ value, the $\mathrm{NIH}-$ 3T3 cells were more sensitive to the $\mathrm{ZnO}-\mathrm{NP}$ than the A549 cells. For NIH-3T3 cells only minor differences in the $\mathrm{IC}_{50}$ values were observed, but for A549 cells in the hydrogel a more than fivefold higher $\mathrm{IC}_{50}$ value was determined. Also, the value for the scaffold model was found to be higher. However, the spheroid model displayed a slightly lower $\mathrm{IC}_{50}$ value in comparison to the $2 \mathrm{D}$ monolayer culture [19].

For $\mathrm{TiO}_{2}-\mathrm{NP}$ no significant reduction was observed in $2 \mathrm{D}$ as well as in 3D (hydrogel and scaffold model) with either cell line (Figure 7). Interestingly, in our previous study we observed that $\mathrm{TiO}_{2}-\mathrm{NP}$ induced the formation of several smaller spheroids [19].

Differences of 2D and 3D cell cultures for toxicity testing have already been reported in the literature. Controversial results showed increased, decreased, or equal cell sensitivity in $3 \mathrm{D}$ cultures when compared to $2 \mathrm{D}$ monolayers [24, 53]. Lee and colleagues showed a reduced toxic effect in HepG2 spheroids for cadmium telluride (CdTe) and for gold nanoparticles in comparison to the 2D cell culture [54]. Drug screening analysis of aflatoxin $\mathrm{B} 1$, amiodarone, valproic acid, and chlorpromazine with HepaRG spheroids [24] and of staurosporine and chlorambucil with HCT116 spheroids [53] demonstrated differences in their half maximal effective concentration $\left(\mathrm{EC}_{50}\right)$ value for $2 \mathrm{D}$ and $3 \mathrm{D}$ cell cultures. In our study we discerned A549 cells in the hydrogel to be less sensitive to $\mathrm{ZnO}-\mathrm{NP}$ than the cells in 2D. In recent studies it was shown that gold nanoparticles can bind to hyaluronic acid hydrogel, thus limiting the cell-nanoparticle interaction [55]. However, for NIH-3T3 cells no significant difference in the sensitivity of 2D cells or 3D hydrogel model cells was observed. Thus, limitations of nanoparticle penetration through the hydrogel can be excluded. In addition, $\mathrm{Xu}$ et al. also demonstrated that cells grown in hyaluronic acid hydrogel were less sensitive to doxorubicin-loaded polymer nanoparticles than cells grown on $2 \mathrm{D}$ monolayers [56].

In summary, the three 3D cell culture models provide different critical concentrations in vitro for $\mathrm{ZnO}-\mathrm{NP}$. 


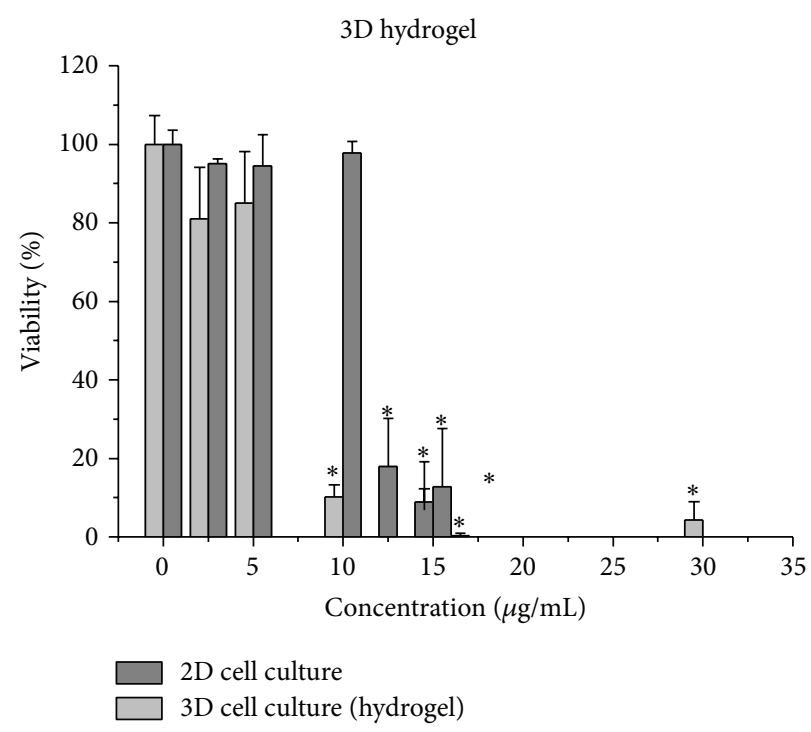

(a) NIH-3T3 cells

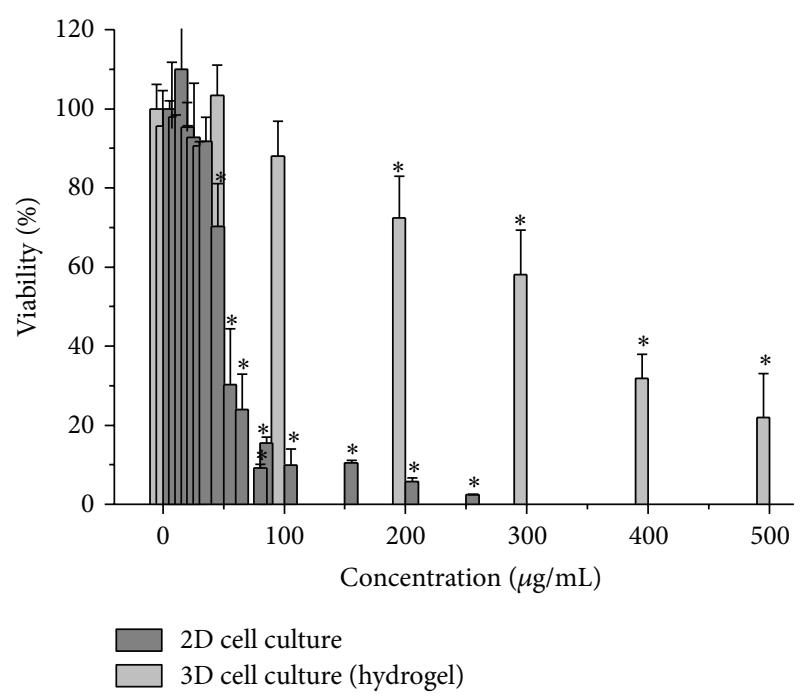

(c) A549 cells

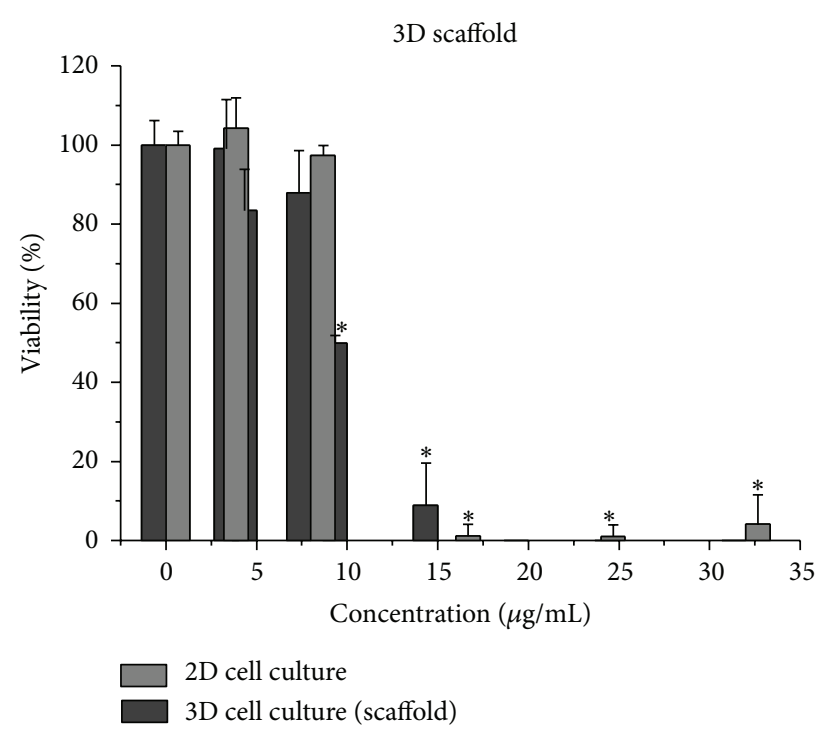

(b) NIH-3T3 cells

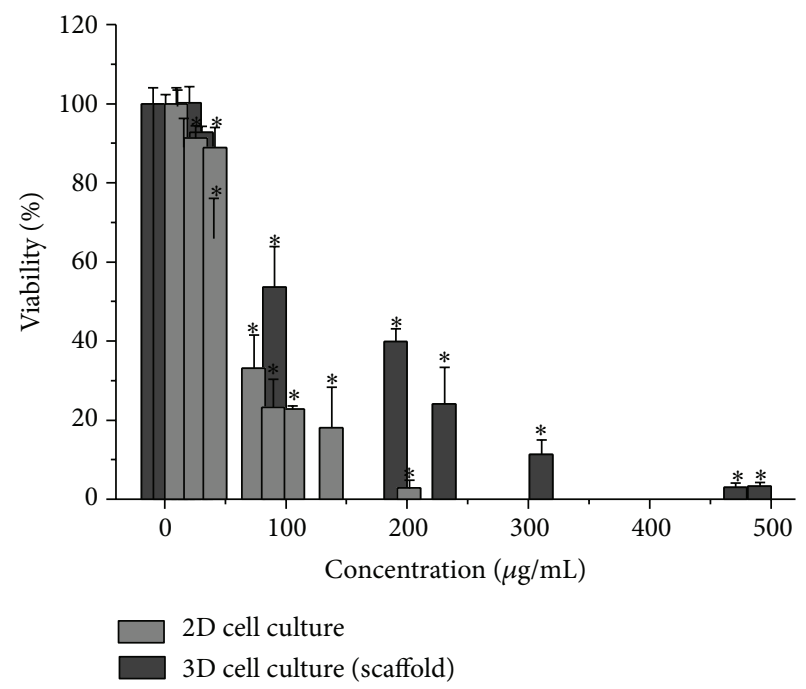

(d) A549 cells

FIgURE 6: Viability of NIH-3T3 cells (a, b) and A549 cells (c, d) after ZnO-NP exposure determined with the CTB assay (a, c) or the MTT assay $(b, d)$. The cells were encapsulated in hydrogel $(a, c)$, seeded on scaffolds $(b, d)$, or cultured on 2D monolayers. The signals of untreated cells were set as $100 \%$. Data points are means \pm SD for $n \geq 3 .{ }^{*} p<0.05$.

Therefore, for a solid prediction for the subsequent in vivo studies the suitability of the 3D model and the later application of the tested nanomaterial has to be in the focus. With spheroids limitations of nutrients, oxygen and other metabolites present in tumor tissues can be investigated [51]. Thus, spheroids are interesting for tumor modeling. This 3D model can be used for nanoparticle development for tumor therapies and nanomedicine. In contrast, the hydrogel and the scaffold 3D model are more representative to mimic real tissue conditions in the human organism. Formation of model tissues and organs could be realized [51]. These models can find applications to clarify nanoparticle risks and to support industrial nanoparticle development.

\section{Conclusions}

We have developed a hierarchical cell-based screening system for nanomaterial toxicity testing, which is divided in a pre-, a fine-, and a complex-screening. Therefore, a set of high-throughput cytotoxicity assays as well as complex cell culture models such as 3D cell culture or dynamic cultivation were integrated. In future work, the screening system could also be extended to long-term studies using a bioreactor. Initially, in the current study we focused on $\mathrm{ZnO}-\mathrm{NP}$ and $\mathrm{TiO}_{2}-\mathrm{NP}$ because of their frequent use in many applications. In our future studies we will extend our investigations to a large set of different nanoparticles. Therefore, other nanoparticles will be screened as well. Regarding the later 


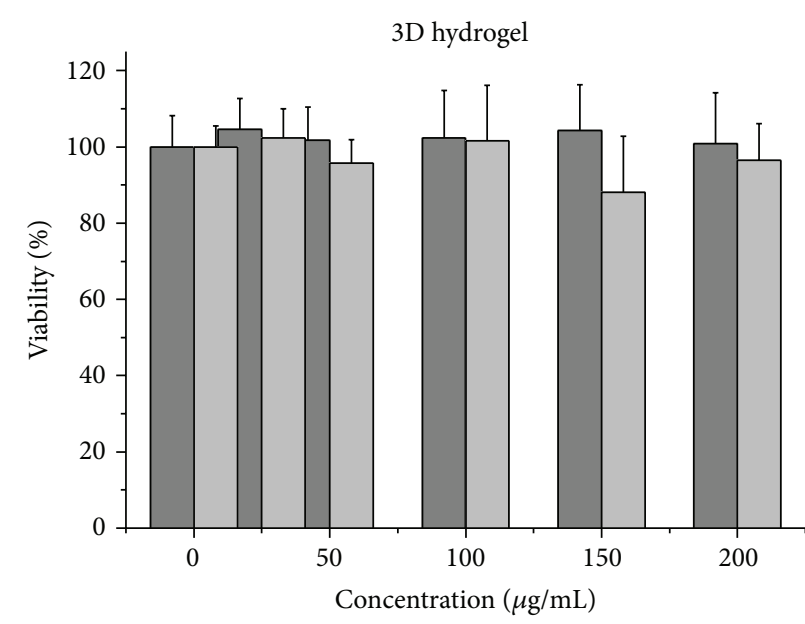

$2 \mathrm{D}$ cell culture

3D cell culture (hydrogel)

(a) NIH-3T3 cells

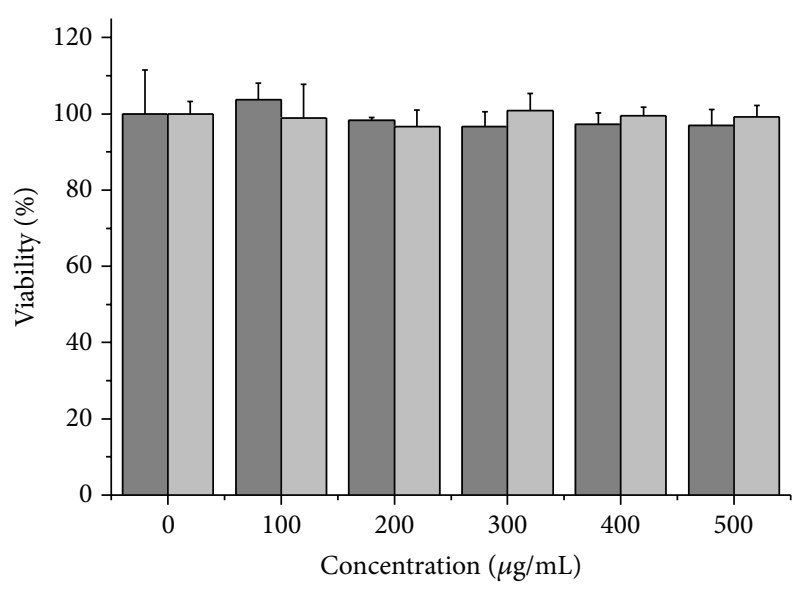

$2 \mathrm{D}$ cell culture

3D cell culture (hydrogel)

(c) A549 cells

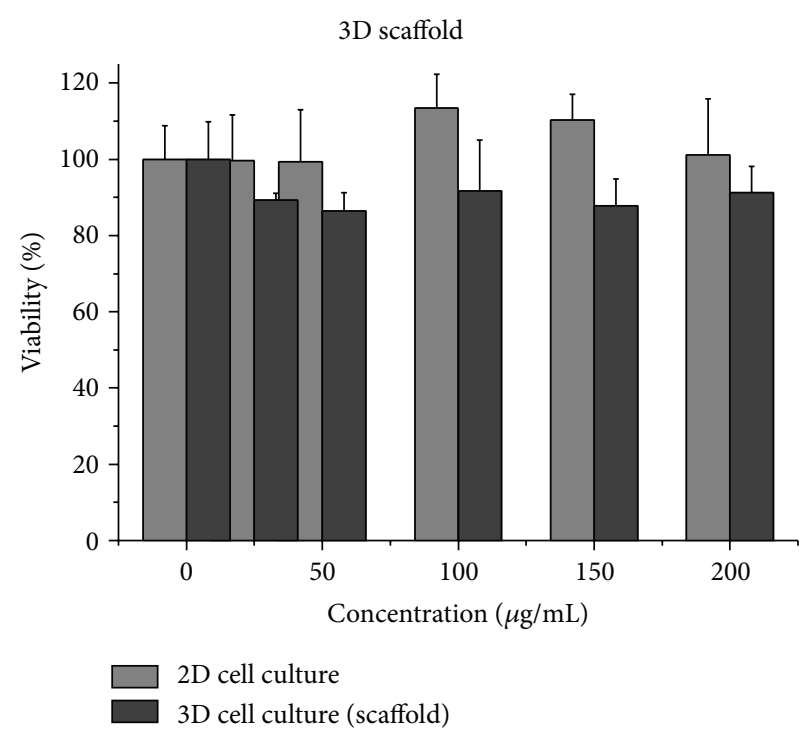

(b) NIH-3T3 cells

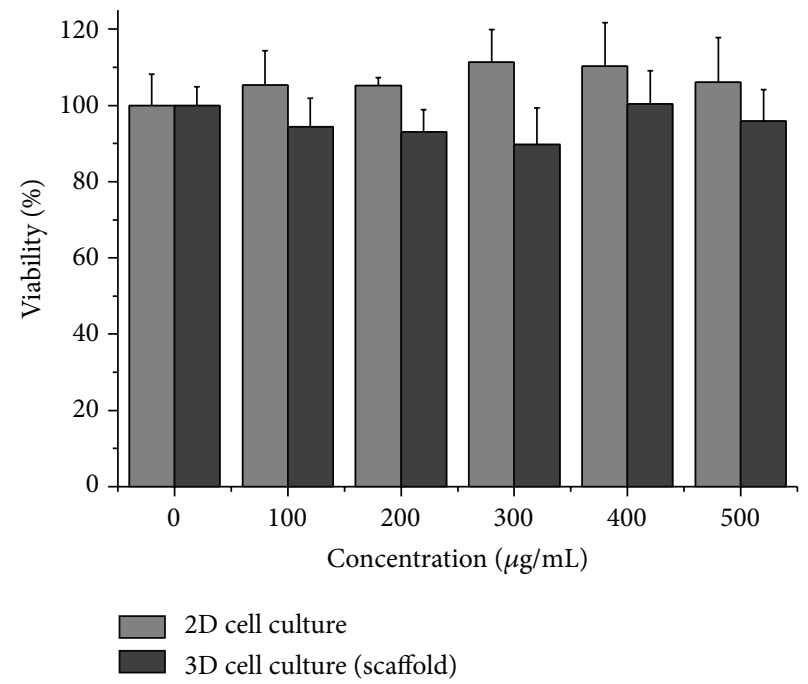

(d) A549 cells

Figure 7: Viability of NIH-3T3 cells (a, b) and A549 cells (c, d) after $\mathrm{TiO}_{2}-\mathrm{NP}$ exposure determined with the CTB assay (a, c) or the MTT assay $(b, d)$. The cells were encapsulated in hydrogel $(a, c)$, seeded on scaffolds $(b, d)$, or cultured on 2D monolayers. The signals of untreated cells were set as $100 \%$. Data points are means \pm SD for $n \geq 3$.

application, the effects of the nanoparticles can be examined in suspension, coatings, or extract media. A high amount of nanomaterials can be analyzed extensively, so that only for selected nanoparticles the application of in vivo studies will be needed. Indeed, in vivo studies cannot be replaced entirely but can be significantly reduced applying our screening system. As case studies, the effects of zinc oxide ( $\mathrm{ZnO}-$ NP) and titanium dioxide nanoparticles $\left(\mathrm{TiO}_{2}-\mathrm{NP}\right)$ were screened. $\mathrm{ZnO}-\mathrm{NP}$ revealed cytotoxic effects to mammalian cells in $2 \mathrm{D}$ cell culture as well as in $3 \mathrm{D}$ cell culture, thus reducing cell viability and inducing inflammation and oxidative stress. On the contrary, for $\mathrm{TiO}_{2}-\mathrm{NP}$ no significant variation was observed with the used methods. We clearly demonstrated that assays have limitations and that the choice of the cell line may affect the results. In comparison to NIH3 T3 cells, A549 cells were less sensitive to the investigated nanoparticles and did not adhere to the $3 \mathrm{D}$ hydrogels. While microscopic detection of morphology changes was possible in $2 \mathrm{D}$ cell cultures, this method was critical in $3 \mathrm{D}$ cell cultures to identify toxic nanoparticles. Electric CellSubstrate Impedance Sensing (ECIS) measurements provide an excellent method for the noninvasive online monitoring of cellular responses to nanoparticles and were hence placed in the fine-screening part of the overall assay. Interference of dyes with the nanoparticles can be excluded employing this method.

In conclusion, the developed screening system can bridge the gap between a constantly increasing nanotechnology and 
comprehensive risk assessment to define safety provisions for workers and customers.

\section{Conflict of Interests}

The authors declare that there is no conflict of interests regarding the publication of this paper.

\section{Acknowledgments}

This work was supported by the European Regional Development Fund (EFRE Project "Nanokomp," Grant no. 60421066). The authors acknowledge support by Deutsche Forschungsgemeinschaft and Open Access Publishing Fund of Leibniz Universität Hannover.

\section{References}

[1] S. Arora, J. M. Rajwade, and K. M. Paknikar, "Nanotoxicology and in vitro studies: the need of the hour," Toxicology and Applied Pharmacology, vol. 258, no. 2, pp. 151-165, 2012.

[2] A. Kroll, M. H. Pillukat, D. Hahn, and J. Schnekenburger, "Current in vitro methods in nanoparticle risk assessment: limitations and challenges," European Journal of Pharmaceutics and Biopharmaceutics, vol. 72, no. 2, pp. 370-377, 2009.

[3] S. J. Soenen, W. J. Parak, J. Rejman, and B. Manshian, "(Intra)Cellular stability of inorganic nanoparticles: effects on cytotoxicity, particle functionality, and biomedical applications," Chemical Reviews, vol. 115, no. 5, pp. 2109-2135, 2015.

[4] V. M. C. Quent, D. Loessner, T. Friis, J. C. Reichert, and D. W. Hutmacher, "Discrepancies between metabolic activity and DNA content as tool to assess cell proliferation in cancer research," Journal of Cellular and Molecular Medicine, vol. 14, no. 4, pp. 1003-1013, 2010.

[5] S. G. Wang, H. T. Yu, and J. K. Wickliffe, "Limitation of the MTT and XTT assays for measuring cell viability due to superoxide formation induced by nano-scale $\mathrm{TiO}_{2}$, "Toxicology in Vitro, vol. 25, no. 8, pp. 2147-2151, 2011.

[6] C. F. Jones and D. W. Grainger, "In vitro assessments of nanomaterial toxicity," Advanced Drug Delivery Reviews, vol. 61, no. 6, pp. 438-456, 2009.

[7] K. Fujita, M. Horie, H. Kato et al., "Effects of ultrafine $\mathrm{TiO}_{2}$ particles on gene expression profile in human keratinocytes without illumination: involvement of extracellular matrix and cell adhesion," Toxicology Letters, vol. 191, no. 2-3, pp. 109-117, 2009.

[8] X. Han, N. Corson, P. Wade-Mercer et al., "Assessing the relevance of in vitro studies in nanotoxicology by examining correlations between in vitro and in vivo data," Toxicology, vol. 297, no. 1-3, pp. 1-9, 2012.

[9] H. W. Kim, E.-K. Ahn, B. K. Jee, H.-K. Yoon, K. H. Lee, and Y. Lim, "Nanoparticulate-induced toxicity and related mechanism in vitro and in vivo," Journal of Nanoparticle Research, vol. 11, no. 1, pp. 55-65, 2009.

[10] I.-L. Hsiao and Y.-J. Huang, "Titanium oxide shell coatings decrease the cytotoxicity of $\mathrm{ZnO}$ nanoparticles," Chemical Research in Toxicology, vol. 24, no. 3, pp. 303-313, 2011.

[11] H. Fukui, M. Horie, S. Endoh et al., "Association of zinc ion release and oxidative stress induced by intratracheal instillation of $\mathrm{ZnO}$ nanoparticles to rat lung," Chemico-Biological Interactions, vol. 198, no. 1-3, pp. 29-37, 2012.
[12] S. Li, W. Song, and M. Gao, "Single and combined cytotoxicity research of propiconazole and nano-zinc oxide on the NIH/3T3 cell," Procedia Environmental Sciences, vol. 18, pp. 100-105, 2013, Proceedings of the International Symposium on Environmental Science and Technology (ISEST '13).

[13] S. Wagner, S. Münzer, P. Behrens, T. Scheper, D. Bahnemann, and C. Kasper, "Cytotoxicity of titanium and silicon dioxide nanoparticles," Journal of Physics: Conference Series, vol. 170, Article ID 012022, 2009.

[14] E. Demir, H. Akça, F. Turna et al., "Genotoxic and celltransforming effects of titanium dioxide nanoparticles," Environmental Research, vol. 136, pp. 300-308, 2015.

[15] H. Shi, R. Magaye, V. Castranova, and J. Zhao, "Titanium dioxide nanoparticles: a review of current toxicological data," Particle and Fibre Toxicology, vol. 10, no. 1, article 15, 2013.

[16] S. Aueviriyavit, D. Phummiratch, K. Kulthong, and R. Maniratanachote, "Titanium dioxide nanoparticles-mediated in vitro cytotoxicity does not induce Hsp70 and Grp78 expression in human bronchial epithelial A549 cells," Biological Trace Element Research, vol. 149, no. 1, pp. 123-132, 2012.

[17] J. Z. Bloh, R. Dillert, and D. W. Bahnemann, "Rutheniummodified zinc oxide, a highly active vis-photocatalyst: the nature and reactivity of photoactive centres," Physical Chemistry Chemical Physics, vol. 16, no. 12, pp. 5833-5845, 2014.

[18] J. Z. Bloh, R. Dillert, and D. W. Bahnemann, "Transition metalmodified zinc oxides for UV and visible light photocatalysis," Environmental Science and Pollution Research, vol. 19, no. 9, pp. 3688-3695, 2012.

[19] F. Sambale, A. Lavrentieva, F. Stahl et al., "Three dimensional spheroid cell culture for nanoparticle safety testing," Journal of Biotechnology, vol. 205, pp. 120-129, 2015.

[20] National Standards Authority of Ireland (NSAI), Biological Evaluation of Medical Devices-Part 12: Sample Preparation and Reference Materials (ISO 10993-12:2012), National Standards Authority of Ireland (NSAI), 2012.

[21] F. Denizot and R. Lang, "Rapid colorimetric assay for cell growth and survival. Modifications to the tetrazolium dye procedure giving improved sensitivity and reliability," Journal of Immunological Methods, vol. 89, no. 2, pp. 271-277, 1986.

[22] S. Bruns, Y. Stark, M. Wieland, F. Stahl, C. Kasper, and T. Scheper, "Fast and efficient screening system for new biomaterials in tissue engineering: a model for peripheral nerve regeneration," Journal of Biomedical Materials Research A, vol. 81, no. 3, pp. 736-747, 2007.

[23] A. Kroll, C. Dierker, C. Rommel et al., "Cytotoxicity screening of 23 engineered nanomaterials using a test matrix of ten cell lines and three different assays," Particle and Fibre Toxicology, vol. 8, article 9, 2011.

[24] D. Mueller, L. Krämer, E. Hoffmann, S. Klein, and F. Noor, “3D organotypic HepaRG cultures as in vitro model for acute and repeated dose toxicity studies," Toxicology in Vitro, vol. 28, no. 1, pp. 104-112, 2014.

[25] E. L. da Rocha, L. M. Porto, and C. R. Rambo, "Nanotechnology meets 3D in vitro models: tissue engineered tumors and cancer therapies," Materials Science and Engineering C, vol. 34, no. 1, pp. 270-279, 2014.

[26] L. Taccola, V. Raffa, C. Riggio et al., "Zinc oxide nanoparticles as selective killers of proliferating cells," International Journal of Nanomedicine, vol. 6, pp. 1129-1140, 2011.

[27] U. G. Sauer, S. Vogel, A. Hess et al., "In vivo-in vitro comparison of acute respiratory tract toxicity using human $3 \mathrm{D}$ airway 
epithelial models and human A549 and murine 3T3 monolayer cell systems," Toxicology in Vitro, vol. 27, no. 1, pp. 174-190, 2013.

[28] C. Zink, H. Hall, D. M. Brunette, and N. D. Spencer, "Orthogonal nanometer-micrometer roughness gradients probe morphological influences on cell behavior," Biomaterials, vol. 33, no. 32, pp. 8055-8061, 2012.

[29] D. D. Deligianni, N. D. Katsala, P. G. Koutsoukos, and Y. F. Missirlis, "Effect of surface roughness of hydroxyapatite on human bone marrow cell adhesion, proliferation, differentiation and detachment strength," Biomaterials, vol. 22, no. 1, pp. 87-96, 2001.

[30] L. Ventrelli, T. Fujie, S. D. Turco, G. Basta, B. Mazzolai, and V. Mattoli, "Influence of nanoparticle-embedded polymeric surfaces on cellular adhesion, proliferation, and differentiation," Journal of Biomedical Materials Research A, vol. 102, no. 8, pp. 2652-2661, 2014.

[31] J. E. Paddle-Ledinek, Z. Nasa, and H. J. Cleland, "Effect of different wound dressings on cell viability and proliferation," Plastic \& Reconstructive Surgery, vol. 117, no. 7, pp. 110S-118S, 2006.

[32] J. M. Seiffert, M.-O. Baradez, V. Nischwitz, T. Lekishvili, H. Goenaga-Infante, and D. Marshall, "Dynamic monitoring of metal oxide nanoparticle toxicity by label free impedance sensing," Chemical Research in Toxicology, vol. 25, no. 1, pp. 140152, 2012.

[33] Z. Yan, L. Xu, J. Han et al., “Transcriptional and posttranscriptional regulation and endocytosis were involved in zinc oxide nanoparticle-induced interleukin-8 overexpression in human bronchial epithelial cells," Cell Biology and Toxicology, vol. 30, no. 2, pp. 79-88, 2014.

[34] S. Singh, T. Shi, R. Duffin et al., "Endocytosis, oxidative stress and IL-8 expression in human lung epithelial cells upon treatment with fine and ultrafine $\mathrm{TiO}_{2}$ : role of the specific surface area and of surface methylation of the particles," Toxicology and Applied Pharmacology, vol. 222, no. 2, pp. 141-151, 2007.

[35] J. T. Silver and E. G. Noble, "Regulation of survival gene hsp70," Cell Stress and Chaperones, vol. 17, no. 1, pp. 1-9, 2012.

[36] J. Okuda-Shimazaki, S. Takaku, K. Kanehira, S. Sonezaki, and A. Taniguchi, "Effects of titanium dioxide nanoparticle aggregate size on gene expression," International Journal of Molecular Sciences, vol. 11, no. 6, pp. 2383-2392, 2010.

[37] J. K. Chen, C. Ho, H. Chang et al., "Particulate nature of inhaled zinc oxide nanoparticles determines systemic effects and mechanisms of pulmonary inflammation in mice," Nanotoxicology, vol. 9, no. 1, pp. 43-53, 2015.

[38] E. Frohlich, C. Meindl, K. Wagner, G. Leitinger, and E. Roblegg, "Use of whole genome expression analysis in the toxicity screening of nanoparticles," Toxicology and Applied Pharmacology, vol. 280, no. 2, pp. 272-284, 2014.

[39] Q. Sun, D. Tan, Y. Ze et al., "Pulmotoxicological effects caused by long-term titanium dioxide nanoparticles exposure in mice," Journal of Hazardous Materials, vol. 235-236, pp. 47-53, 2012.

[40] S. Gui, Z. Zhang, L. Zheng et al., "Molecular mechanism of kidney injury of mice caused by exposure to titanium dioxide nanoparticles," Journal of Hazardous Materials, vol. 195, pp. 365-370, 2011.

[41] M. Ahamed, R. Posgai, T. J. Gorey, M. Nielsen, S. M. Hussain, and J. J. Rowe, "Silver nanoparticles induced heat shock protein 70, oxidative stress and apoptosis in Drosophila melanogaster," Toxicology and Applied Pharmacology, vol. 242, no. 3, pp. 263269, 2010.
[42] M. Ahamed, M. A. Siddiqui, M. J. Akhtar, I. Ahmad, A. B. Pant, and H. A. Alhadlaq, "Genotoxic potential of copper oxide nanoparticles in human lung epithelial cells," Biochemical and Biophysical Research Communications, vol. 396, no. 2, pp. 578583, 2010.

[43] P. Chen, K. Kanehira, S. Sonezaki, and A. Taniguchi, "Detection of cellular response to titanium dioxide nanoparticle agglomerates by sensor cells using heat shock protein promoter," Biotechnology and Bioengineering, vol. 109, no. 12, pp. 3112-3118, 2012.

[44] Y. J. Chae, C. H. Pham, J. Lee, E. Bae, J. Yi, and M. B. Gu, "Evaluation of the toxic impact of silver nanoparticles on Japanese medaka (Oryzias latipes)," Aquatic Toxicology, vol. 94, no. 4, pp. 320-327, 2009.

[45] C. H. Pham, J. Yi, and M. B. Gu, "Biomarker gene response in male Medaka (Oryzias latipes) chronically exposed to silver nanoparticle," Ecotoxicology and Environmental Safety, vol. 78, pp. 239-245, 2012.

[46] L. Foucaud, S. Goulaouic, A. Bennasroune et al., "Oxidative stress induction by nanoparticles in THP-1 cells with 4-HNE production: stress biomarker or oxidative stress signalling molecule?" Toxicology in Vitro, vol. 24, no. 6, pp. 1512-1520, 2010.

[47] R. Posgai, M. Ahamed, S. M. Hussain, J. J. Rowe, and M. G. Nielsen, "Inhalation method for delivery of nanoparticles to the Drosophila respiratory system for toxicity testing," Science of the Total Environment, vol. 408, no. 2, pp. 439-443, 2009.

[48] K. B. Male, M. Hamzeh, J. Montes, A. C. W. Leung, and J. H. T. Luong, "Monitoring of potential cytotoxic and inhibitory effects of titanium dioxide using on-line and non-invasive cell-based impedance spectroscopy," Analytica Chimica Acta, vol. 777, pp. 78-85, 2013.

[49] X. Zhu, E. Hondroulis, W. Liu, and C.-Z. Li, "Biosensing approaches for rapid genotoxicity and cytotoxicity assays upon nanomaterial exposure," Small, vol. 9, no. 9-10, pp. 1821-1830, 2013.

[50] B. Moe, S. Gabos, and X.-F. Li, "Real-time cell-microelectronic sensing of nanoparticle-induced cytotoxic effects," Analytica Chimica Acta, vol. 789, pp. 83-90, 2013.

[51] Z. Li and Z. Cui, "Three-dimensional perfused cell culture," Biotechnology Advances, vol. 32, no. 2, pp. 243-254, 2014.

[52] F. Ruedinger, A. Lavrentieva, C. Blume, I. Pepelanova, and T. Scheper, "Hydrogels for 3D mammalian cell culture: a starting guide for laboratory practice," Applied Microbiology and Biotechnology, vol. 99, no. 2, pp. 623-636, 2015.

[53] M. Drewitz, M. Helbling, N. Fried et al., "Towards automated production and drug sensitivity testing using scaffold-free spherical tumor microtissues," Biotechnology Journal, vol. 6, no. 12, pp. 1488-1496, 2011.

[54] J. Lee, D. Lilly, C. Doty, P. Podsiadlo, and N. Kotov, "In vitro toxicity testing of nanoparticles in 3D cell culture," Small, vol. 5, no. 10, pp. 1213-1221, 2009.

[55] A. I. Astashkina, C. F. Jones, G. Thiagarajan et al., "Nanoparticle toxicity assessment using an in vitro 3-D kidney organoid culture model," Biomaterials, vol. 35, no. 24, pp. 6323-6331, 2014.

[56] X. Xu, C. R. Sabanayagam, D. A. Harrington, M. C. FarachCarson, and X. Jia, "A hydrogel-based tumor model for the evaluation of nanoparticle-based cancer therapeutics," Biomaterials, vol. 35, no. 10, pp. 3319-3330, 2014. 

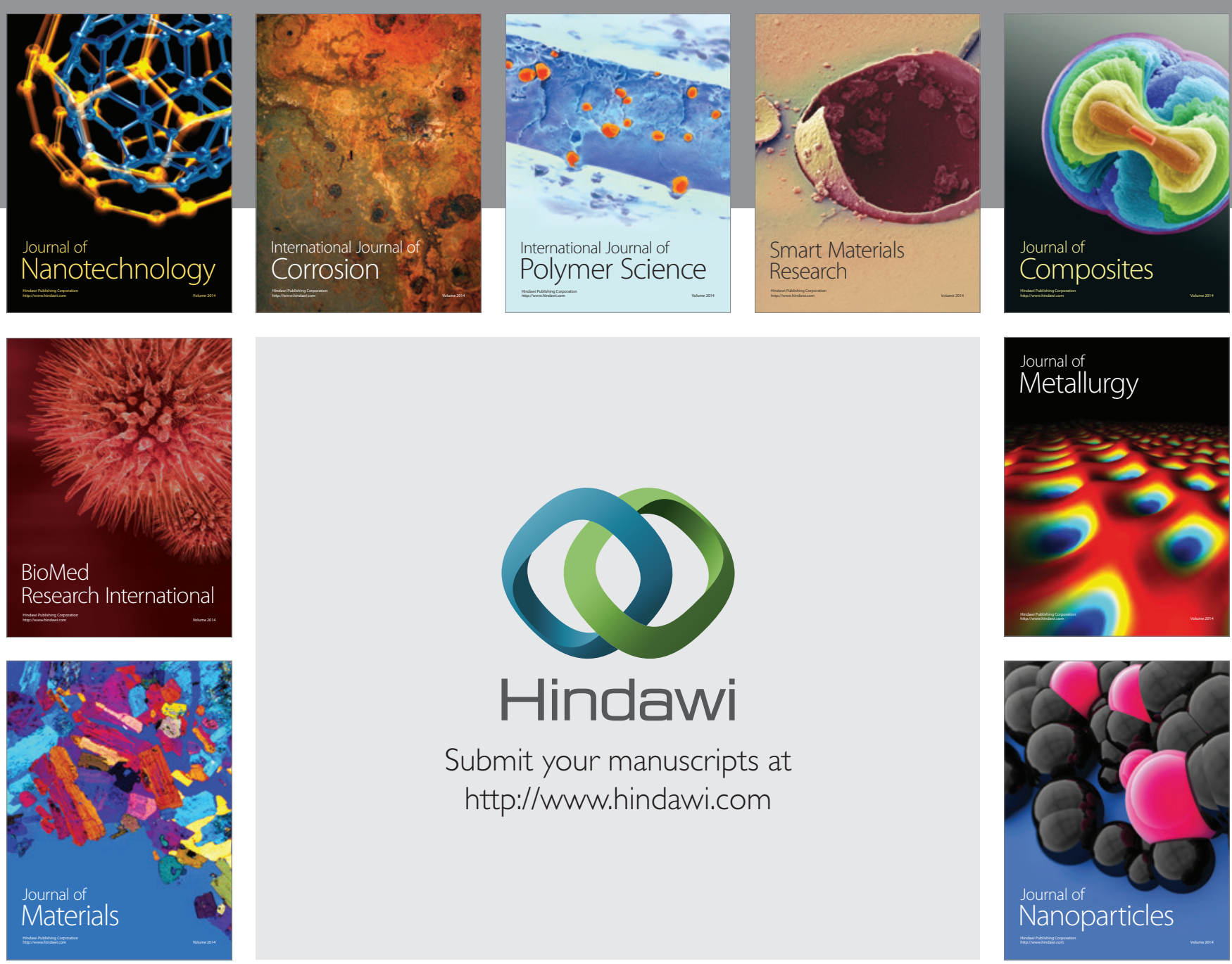

Submit your manuscripts at http://www.hindawi.com
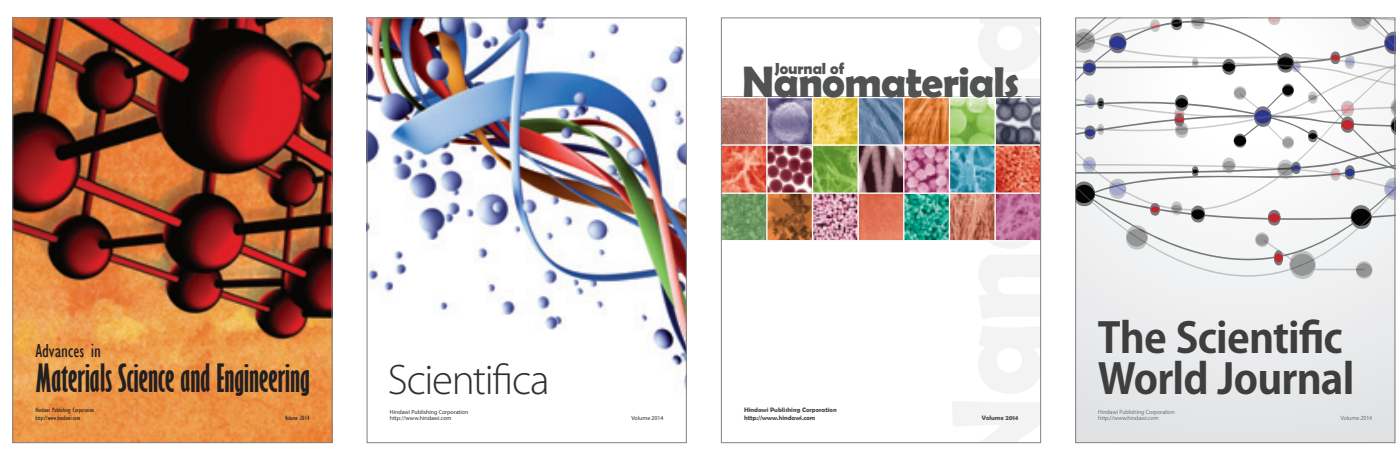

\section{The Scientific World Journal}
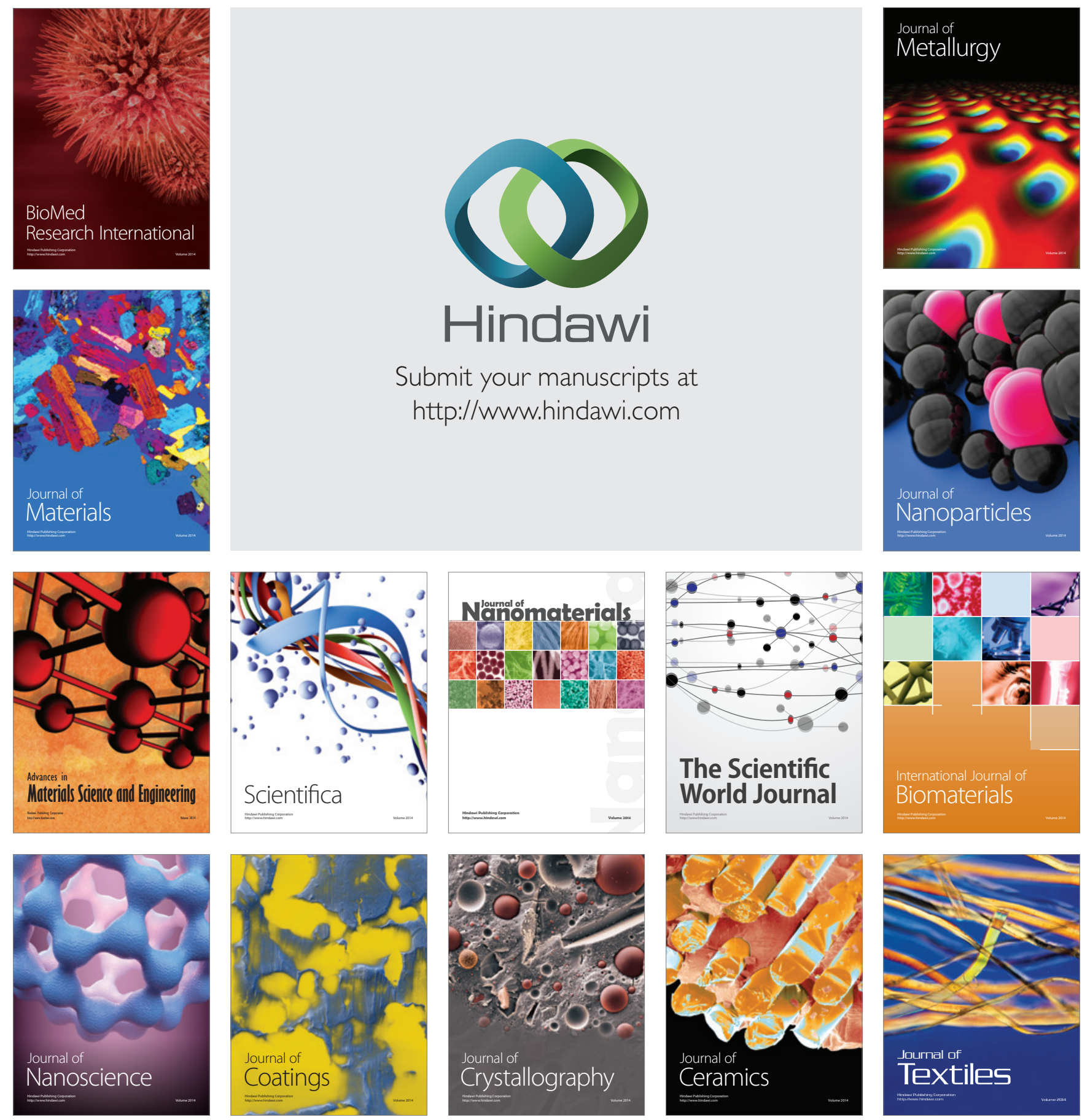